\title{
Responding to Human Rights Violations in Africa
} Assessing the Role of the African Commission and Court on Human and Peoples' Rights (1987-2018)

\section{Manisuli Ssenyonjo}

Professor of International Law and Human Rights, Brunel University London manisuli.ssenyonjo@brunel.ac.uk

\begin{abstract}
This article examines the main achievements and challenges of Africa's two regional bodies established to ensure the implementation of human rights in Africa. It makes an assessment of the role of Africa's oldest regional human rights body, the African Commission on Human and Peoples' Rights (African Commission) in the last 31 years of its operation (from 1987-March 2018). It also considers the judicial role of the African Court on Human and Peoples' Rights (African Court) in the last 12 years of its operation (from 2006-March 2018). The increasing contribution of both the Commission and the Court to the protection of human rights under the African Charter on Human and Peoples' Rights is rarely subjected to scrutiny in mainstream human rights literature. The article is limited to the consideration of the Commission's contribution with respect to: (i) decisions on admissibility of communications concerning mainly exhaustion of domestic remedies; (ii) decisions on merits of communications; (iii) adoption of resolutions, principles/guidelines, general comments, model laws and advisory opinions; (iv) special rapporteurs and working groups to deal with thematic human rights issues; (v) consideration of State reports and conducting on-site visits; and (vi) referral of communications to the African Court involving unimplemented interim measures, serious or massive human rights violations, or the Commission's findings on admissibility and merits.
\end{abstract}

\section{Keywords}

African Commission/Court on Human and Peoples' Rights - exhaustion of domestic remedies - communications - resolutions - general comments - advisory opinions special rapporteurs - State reports - access to African Court

(C) SSENYONJO, 2018 | DOI 10.1163/22131035-00701003

This is an open access article distributed under the terms of the prevailing CC-BY license at the time of publication. 
Africa is the world's second largest and second-most populous continent with a population of over 1.2 billion. ${ }^{1}$ It has historically been a region with widespread human rights violations manifested in several forms including slavery, ${ }^{2}$ (neo)colonialism, ${ }^{3}$ apartheid, ${ }^{4}$ and multidimensional (extreme) poverty. ${ }^{5}$ During colonialism Africa's human and material resources were 'largely exploited for the benefit of outside powers' ${ }^{6}$ This left Africa in poverty which reflects an acute 'deprivation of the resources, capabilities, choices, security and power necessary for the enjoyment of an adequate standard of living.7

Thus in 1963 the Charter of the Organisation of African Unity (OAU) was adopted to, among others, 'achieve a better life for the peoples of Africa' and to 'eradicate all forms of colonialism from Africa'. ${ }^{8}$ Although the preamble to the OAU Charter reaffirmed adherence to the Charter of the United Nations ${ }^{9}$ and the Universal Declaration of Human Rights (UDHR), ${ }^{10}$ the main focus of the OAU was to eliminate colonialism in African states. This required a regional system to respect, protect and fulfil human rights. The African Charter on $\mathrm{Hu}-$ man and Peoples' Rights (African Charter) was adopted by the eighteenth

1 See Worldometers, Africa Population at <http://www.worldometers.info/world -population/africa-population/>.

2 See e.g. Joseph E Inikori and Stanley L Engerman, Atlantic Slave Trade: Effects on Economies, Societies and Peoples in Africa, the America and Europe (Duke University Press, 1992).

3 Walter Rodney, How Europe Underdeveloped Africa (Bogle L'Ouverhure Publications, 1988); Mahmood Mamdani, Citizen and Subject: Contemporary Africa and the Legacy of Late Colonialism (Princeton University Press, 1996).

4 See Raphael B Alade, Winds of Change in South Africa: From Apartheid to Freedom (Stirling-Horden Publishers, 2008).

5 See Kathleen Beegle et al., Poverty in a Rising Africa (International Bank for Reconstruction and Development/The World Bank, 2016).

6 Social and Economic Rights Action Centre and the Centre for Economic and Social Rights $v$ Nigeria, (SERAC v Nigeria), Communication 155/96, 15th Annual Activity Report, 2001; (2001) AHRLR 60 para 56.

7 Committee on Economic, Social and Cultural Rights (CESCR), Statement on Poverty and the International Covenant on Economic, Social and Cultural Rights, E/C.12/2001/10(10 May 2001) para 8.

8 Charter of the Organisation of African Unity, 479 UNTS 39, adopted 25 May 1963, entered into force 13 September 1963, Art II, <https://au.int/sites/default/files/treaties/7759-sl-oau _charter_1963_o.pdf >.

9 Charter of the United Nations, 24 October 1945, 1 UNTS XVI.

10 Universal Declaration of Human Rights, GA res. 217A (III), UN Doc A/810 at 71 (1948). 
Assembly of Heads of State and Government of the OAU in June 1981 and entered into force on 21 October 1986." After achieving its main objective of the liberation of Africa from colonialism and apartheid, the OAU was replaced by the African Union $(\mathrm{AU})$ in 2000. ${ }^{12}$ One of the $\mathrm{AU}$ objectives is to 'promote and protect human and peoples' rights in accordance with the African Charter and 'other relevant human rights instruments.'13

The African Charter, which has been ratified by $54 \mathrm{AU}$ member States, except the Kingdom of Morocco (which re-joined the AU in January 2017), marked the birth of the African regional human rights system. ${ }^{14}$ Over the years several other human rights treaties have been adopted in Africa to strengthen the protection of rights of vulnerable groups including refugees, ${ }^{15}$ children, ${ }^{16}$ women, ${ }^{17}$ youth, ${ }^{18}$ internally displaced persons, ${ }^{19}$ and older persons. ${ }^{20}$ In 1987 the OAU Assembly elected 11 members of the African Commission on Human and Peoples' Rights (the African Commission), which remains the main African

11 African Charter on Human and Peoples' Rights, OAU Doc. CAB/LEg $/ 67 / 3$ rev. 5, 21 ILM 58 (1982).

12 Constitutive Act of the African Union, OAU Doc. CAB/LEG/23.15, adopted 11 July 200o, entered into force 26 May 2001, <https://au.int/en/constitutive-act>.

13 Ibid, Art 3(h).

14 See generally Manisuli Ssenyonjo (ed), The African Regional Human Rights System (Martinus Nijhoff Publishers, 2012). At the time of writing (in 2018) Morocco was the only AU member State that had not yet ratified the African Charter.

15 OAU Convention Governing the Specific Aspects of Refugee Problems in Africa, 1001 UNTS 45, adopted 10 September 1969, entered into force 20 January 1974, <https://au.int/en/ treaties/oau-convention-governing-specific-aspects-refugee-problems-africa $>$.

16 African Charter on the Rights and Welfare of the Child, OAU Doc. CAB/LEG/24.9/49, adopted 1 July 1990, entered into force 29 November 1999, <https://au.int/en/treaties/ african-charter-rights-and-welfare-child>.

17 Protocol to the African Charter on Human and Peoples' Rights on the Rights of Women in Africa (Maputo Protocol), adopted 11 July 2003, entered into force 25 November 2005, $<$ https://au.int/en/treaties/protocol-african-charter-human-and-peoples-rights-rights -women-africa $>$.

18 African Youth Charter, adopted 2 July 20o6, entered into force 8 August 2009, <https:// au.int/en/treaties/african-youth-charter>.

19 African Union Convention for the Protection and Assistance of Internally Displaced Persons in Africa, adopted 23 October 2009, entered into force 24 May 2017, <https://au.int/ en/treaties/african-union-convention-protection-and-assistance-internally-displaced -persons-africa $>$.

20 Protocol to the African Charter on Human and Peoples' Rights on the Rights of Older Persons, adopted 31 January 2016, <https://au.int/en/treaties/protocol-african-charter -human-and-peoples\%E2\%80\%99-rights-rights-older-persons $>$. 
regional quasi-judicial supervisory body for the protection of human rights in Africa. ${ }^{21}$ The Commission receives and considers cases (called 'communications') alleging human rights violations by any State party to the African Charter and makes quasi-judicial 'recommendations'. The jurisdiction of the Commission is compulsory and automatic as it extends to all States parties to the African Charter. The African Court on Human and Peoples' Rights (the African Court) complements the protective mandate of the African Commission by providing legally binding judicial decisions since the Court became operational in July 2006. ${ }^{22}$ The Court has jurisdiction to determine 'all cases and disputes' submitted to it concerning the interpretation and application of the African Charter and 'any other human rights instrument' (including UN instruments) ratified by the States concerned. ${ }^{23}$ The future court intended to replace the existing African Court, the 'African Court of Justice and Human Rights', yet to be established is not discussed in this article since it is not operational. ${ }^{24}$ For the same reason, the article does not examine the yet-to-be-established 'African Court of Justice and Human and Peoples' Rights' with jurisdiction, inter alia, over international and transnational crimes. ${ }^{25}$

In 2018 the African Charter had marked 37 years since its adoption (in 1981), and 32 years since its entry into force (in 1986). In 2018 Africa's quasi-judicial supervisory body, the African Commission, marked 31 years since it became

21 See African Commission on Human and Peoples' Rights, <http://www.achpr.org/>; R Murray and D Long, The Implementation of the Findings of the African Commission on Human and Peoples Rights (Cambridge University Press, 2015).

22 Protocol to the African Charter on Human and Peoples' Rights on the Establishment of An African Court on Human and Peoples' Rights, adopted by then OAU Member States in Ouagadougou, Burkina Faso, on 10 June 1998, entered into force on 25 January 2004, Art 2; African Court on Human and Peoples' Rights, <http://www.african-court.org/en/>.

23 African Court Protocol, (n 22), Art 3.

24 Protocol on the Statute of the African Court of Justice and Human Rights, and Statute of the African Court of Justice and Human Rights, adopted 1 July 2008, <https://au.int/en/ treaties/protocol-statute-african-court-justice-and-human-rights $>$. By March 2018, only six States (namely Benin, Burkina Faso, Congo, Libya, Liberia and Mali) had ratified it, out of the required 15 for the Protocol and Statute annexed to it to enter into force.

25 Protocol on Amendments to the Protocol on the Statute of the African Court of Justice and Human Rights, and Statute of the African Court of Justice and Human Rights, adopted 27 June 2014, <https://au.int/en/treaties/protocol-amendments-protocol-statute-african -court-justice-and-human-rights $>$. By March 2018, no single State out of the required 15 for the Protocol and Statute annexed to it to enter into force had ratified it though 11 had signed it namely Benin, Chad, Comoros, Congo, Ghana, Guinea-Bissau, Kenya, Mauritania, Sierra Leone, Sao Tome \& Principe, and Uganda. 
operational in 1987 and its judicial body, the African Court, had been in existence for 12 years (since it became operational in 2006). Against the above background, this article examines the main achievements and challenges of the African Commission between 1987-2018 (Section 2) and the African Court in the first 12 years of its operation from 2006-2018 (Section 3). These are the two main bodies established to ensure the implementation of human rights in Africa. Due to space constraint, the third body, the African Committee of Experts on the Rights and Welfare of the Child, is outside the scope of this article. ${ }^{26}$ The Committee is not among the entities that can refer cases to the African Court. ${ }^{27}$ Similarly, the scope of the article does not extend to sub-regional courts in Africa (e.g. the Economic Community of West African States (ECOWAS) Community Court of Justice, and the East African Court of Justice) exercising some human rights jurisdiction. Section 4 makes concluding observations.

\section{African Commission on Human and Peoples' Rights: Achievements and Challenges}

\subsection{Background and Context}

The African Commission was established in 1987 following the entry into force of the African Charter in $1986 .{ }^{28}$ Its headquarters are based in Banjul, The Gambia. The Commission consists of 'eleven members chosen from amongst African personalities of the highest reputation, known for their high morality,

26 The African Committee of Experts on the Rights and Welfare of the Child (ACERWC) was established in 2001. For more information see ACERWC, <http://www.acerwc.org/>. In early 2018, the Committee had decided only three cases available at $<$ http://www.acerwc .org/communications/>: Institute for Human Rights and Open Society Justice Initiative (on behalf of Children of Nubian Descent in Kenya) $v$ Kenya, Communication 2/2009, Dec 2/ Com/oo2/2009, 22 March 2011; Michelo Hunsungule and Others (on Behalf of Children in Northern Uganda) $v$ The Government of Uganda, Communication No. 1/2005, Decision No 001/Com/001/2005, 15-19 April 2013; The Centre for Human Rights (University of Pretoria) and La Rencontre Africaine pour la Defense Des Droits de l'homme (Senegal) v The Government of Senegal, Decision No 003/Com/oo1/2012, 15 April 2014.

27 African Court Protocol, (n 22), Art 5; The African Committee of Experts on the Rights and Welfare of the Child on the Standing of the African Committee of Experts on the Rights and Welfare of the Child before the African Court on Human and Peoples' Rights, Advisory Opinion 2/2013 (5 December 2014); Decision on the Report of the African Committee of Experts on the Rights and Welfare of the Child (ACERWC), EX.CL/Dec.923(XXIX), 13-15 July 2016.

28 African Charter, (n 11), Arts 30-44. 
integrity, impartiality and competence in matters of human and peoples' rights; particular consideration being given to persons having legal experience. ${ }^{29}$ Commissioners are nominated by States parties to the African Charter and elected by the AU Assembly of Heads of State and Government but they are required to 'serve in their personal capacity' on a part-time basis. ${ }^{30}$ However, in the past the independence of some individual commissioners has been questionable on the basis that they were senior civil servants and diplomatic representatives. ${ }^{31}$ For example, in 2003 a commissioner from Mauritania was appointed as a cabinet minister shortly after being elected to the Commission.

The Commission meets twice a year in regular sessions for a period of up to two weeks. The functions of the African Commission include the promotion of human rights through research 'on African problems in the field of human and peoples' rights', dissemination of information, and co-operation with 'other African and international institutions concerned with the promotion and protection of human and peoples' rights'. ${ }^{32}$ It is also empowered to 'ensure the protection of human and peoples' rights' under conditions laid down by the African Charter. ${ }^{33}$ In addition, the Commission has the mandate to 'interpret' all the provisions of the African Charter at the request of a State party, an institution of the AU or an African Organisation recognised by the AU. ${ }^{34}$ It also considers inter-state communications (complaints) by which one State brings a complaint alleging violations of human rights in another State. ${ }^{35}$ Furthermore the Commission considers periodic State reports on the domestic implementation of the African Charter ${ }^{36}$ and its Protocol on the Rights of women ${ }^{37}$ followed by the adoption of concluding observations. ${ }^{38}$

29 Ibid, Art 31(1).

3o Ibid, Art 31(2).

31 AU Commission, Note Verbale, BC/OLC/66/Vol Xvin (5 April 2005), the AU Commission provided guidelines to AU member States that excluded senior civil servants and diplomatic representatives from being elected to new appointments to the Commission.

32 Ibid, Art 45(1).

33 Ibid, $45(2)$.

34 Ibid, 45(3).

35 Ibid, Arts 47-59; Democratic Republic of the Congo v Burundi, Rwanda and Uganda, Communication 227/99, 20th Activity Report; (2004) AHRLR 19.

36 African Charter, (n 11), Art 62. Each State Party undertakes to submit every two years 'a report on the legislative or other measures taken, with a view to giving effect to the rights and freedoms recognised and guaranteed by the [African] Charter'.

37 Maputo Protocol (n 17) Art 26.

38 African Commission, State Reports and Concluding Observations, <http://www.achpr.org/ states/reports-and-concluding-observations/>. 
In addition, the Commission considers communications or complaints lodged by individuals and non-governmental organisations (NGOs), ${ }^{39}$ subject to meeting the admissibility criteria, ${ }^{40}$ without requiring the complainant to be a victim or a family member of the victim. ${ }^{41}$

\subsection{Achievements of the African Commission 1987-2018}

The main achievements of the Commission include the development of standards on the various provisions of the African Charter through:(i) decisions on admissibility of communications mainly concerning exhaustion of domestic remedies; (ii) decisions on merits of communications; (iii) adoption of resolutions, principles/guidelines, general comments, model laws and advisory opinions; (iv) special rapporteurs and working groups to deal with thematic human rights issues; (v) consideration of State reports and conducting on-site visits; and (vi) referral of communications (unimplemented interim measures, serious or massive human rights violations, or Commission's admissibility and merits finding) to the African Court.

\section{Exhaustion of Domestic Remedies}

The Commission has encouraged African States to develop effective domestic remedies. This is consistent with the fact that the machinery of protection of human rights established by the African Charter is subsidiary to the national systems protecting human rights. Therefore, one of the 'most important' criterion for admissibility of communications before the African Commission, like in other regional human rights systems, ${ }^{42}$ is the exhaustion of domestic (local) remedies according to the generally recognised rules/principles of

39 Individual or NGO communications are not explicitly provided for in the African Charter but have been accepted in the practice of the Commission as 'communications other than those of States parties to the [African] Charter' under Arts $55^{-} 5^{8}$ of the African Charter.

African Charter, (n 11), Art 56 communications must indicate names of authors, be compatible with the African Charter, not be 'written in disparaging or insulting language', not be based exclusively on mass media reports, be sent 'after exhausting local remedies, if any, unless it is obvious that this procedure is unduly prolonged', be submitted within a 'reasonable period from the time' (normally within 6 months from the date of exhaustion of local remedies), and do not deal with cases which have been settled.

41 SERAC v Nigeria, (n 6), para 49.

42 See e.g. European Convention for the Protection of Human Rights and Fundamental Freedoms (as amended), 4 November 1950, ETs 5, Art 35; American Convention on Human Rights, 1144 UNTS 123, Art 46(1)(a). 
international law. ${ }^{43}$ Under Article ${ }^{6}$ (5) of the African Charter, applicants are under an obligation to use the remedies provided by national law which are sufficient to afford redress in respect of the violations of human rights alleged. The Commission considers on merits communications sent 'after exhausting local remedies, if any, unless it is obvious that this procedure is unduly prolonged'.44 Determining whether, or not, an applicant has exhausted domestic remedies requires careful consideration of the personal circumstances of the applicant, as well as the general legal and political context in which the remedies operate.

In order to exhaust available domestic remedies, a victim must generally demonstrate that a final decision from the competent domestic highest court was obtained as regards the particular complaint they wish to make before the Commission. This is significant because the requirement for exhaustion of available domestic remedies gives the first opportunity to the respondent State to remedy or redress an alleged violation of human rights within the framework of its own domestic legal system before being called before an international body. ${ }^{45}$ Thus, communications have been declared inadmissible on account of failure of applicants to indicate that domestic remedies were exhausted or ineffective. ${ }^{46}$ This 'prevents the Commission from acting as a court [or a quasi-judicial body] of first instance rather than a body of last resort,'47

43 African Charter, (n 11), Art 56(5); Law Offices of Ghazi Suleiman v Sudan, Communication 228/99, 16th Annual Activity Report (2002-2003); (2003) AHRLR 144, paras 22-37.

44 African Charter, (n 11), Art 56(5).

45 See e.g. SERAC v Nigeria, (n 6), para 37-39; World Organisation against Torture and Others $v$ Zaire, Communications 25/89, 47/90, 56/91 \& 100/93, 9th Annual Activity Report, (2000) AHRLR 74, para 36; Rencontre Africaine pour la Défense des Droits de l'Homme v Zambia, Communication 71/92, 1oth Annual Activity Report, (2000) AHRLR 321, para 11.

46 See e.g. Association Que Choisir Bénin v Benin, Communication 264/o2, 18th Annual Activity Report, (2005) AHRLR 43, paras 21-32; Filimao Pedro Tivane (represented by Dr. Simeao Cuamba) vMozambique, Communication 434/12, (2016), <http://www.achpr.org/ files/sessions/59th/comunications/434.12/communication_434_eng.pdf>, paras 51-54; Sana Dumbaya $v$ The Gambia, Communication 127/94, 8th annual Activity Report, (2000) AHRLR 103, paras 2 and 3; Ousman Manjang $v$ The Gambia, Communication 131/94, 7th Annual Activity Report, (2000) AHRLR 101, para 1; International Pen (in respect of Kemal alJazouli) v Sudan, Communication 92/93, 8th Annual Activity Report, (2000) AHRLR 296, para 3; Mohamed L. Diakitév Gabon, Communication 73/92, 13th annual Activity Report, (2000) AHrlr 98, para 17; Ms Ceesayv The Gambia, Communication 86/93, 8th Activity Report, (2000) AHRLR 101, para 4.

47 Sir Dawda K. Jawara v The Gambia, Communication 147/95 and 149/96, 13th Activity Report, (2000) AHRLR 107, para 31. 
in line with the principle that post-national norms and institutions are subsidiary to and supplement rather than replace national norms and institutions. The Commission requires that local remedies must be 'available, effective and sufficient' ${ }^{48}$ as well as 'realistic' or 'sufficiently certain' (reasonably accessible, capable of providing redress in respect of the complaint with reasonable prospects of success) not only in theory but also in practice. ${ }^{49}$ It follows that there is no obligation to attempt to use a remedy which is ineffective or inadequate, for example, if national law shows that a remedy, such as an appeal, has no reasonable chances of success.

In Jawara $v$ The Gambia, the complainant was the former Head of State of the Republic of The Gambia. He was overthrown by the military in a coup of July 1994 and tried in absentia. Former Ministers and Members of Parliament of his government were detained and there was terror and fear for lives in the country. The complainant alleged violation of several provisions of the African Charter. In considering whether he had exhausted local remedies, the Commission stated that: 'A remedy is considered available if the petitioner can pursue it without impediment, it is deemed effective if it offers a prospect of success, and it is found sufficient if it is capable of redressing the complaint. ${ }^{\prime}$ The Commission considered that in a situation where the jurisdiction of the courts have been ousted by decrees whose validity cannot be challenged or questioned, as was the position in this case, local remedies are deemed to be both 'unavailable' as well as 'non-existent.'.51 Similarly complainants who are unable to pursue domestic remedies (when outside a State's territory and fear to return for life on account of persecution) are deemed to have constructively exhausted domestic remedies. ${ }^{52}$ Remedies to be exhausted must be of a 'judicial' nature sought from independent sources and 'not subordinated to

48 Ibid, paras 31,35. The Commission relied on DeJong, Baljet \& van den BrinkvThe Netherlands (1984) 8 E HRR 20, para 39. See also Rights International v Nigeria, Communication 215/98, 13th Annual Activity Report, (2000) AHRLR 254, para 23.

49 PurohitandMoorevThe Gambia, Communication 241/01,16th Activity Report,(2003)AHRLR 96, paras 37 and 38; The Nubian Community in Kenya $v$ The Republic of Kenya, Communication 317/2006, (2015), <http://www.achpr.org/files/sessions/17theo/comunications/ 317.06/communication_317.06_eng.pdf $>$, paras $45^{-51}$.

Jawara $v$ The Gambia, (n 47), para 32.

$5^{1}$ Ibid, para 34 .

52 See e.g. Alhassan Abubakarv Ghana, Communication 103/93, 1oth Annual Activity Report, (200o) AHrLR 124, para 6; John D. Ouko v Kenya, Communication 232/99, 14th Annual Activity Report, (2000) AHRLR 135, para 19; Kazeem Aminu v Nigeria, Communication 205/97, 13th Annual Activity Report, (2000) AHRLR 258, para 13. 
the discretionary power of public authorities. ${ }^{53}$ As the Commission noted: 'It would be improper to insist on the complainants seeking remedies from sources which do not operate impartially and have no obligation to decide according to legal principles. ${ }^{.54}$ Consequently, States have to put in place effective and adequate domestic remedies granted by fully independent courts not only in theory but also in practice.

\section{Decisions on Communications on Merits}

In the period 1987-2017, 30 decades of the African Commission, the Commission had received well over 400 communications, nearly all from individuals, organisations or groups alleging violations of human rights in the African Charter. ${ }^{55}$ It handed down about 228 decisions on communications on merits and admissibility including communications declared inadmissible or discontinued due to withdrawal or loss of contact with the complainant. ${ }^{56}$ With the exception of one inter-state complaint only, ${ }^{57}$ all other complaints have been submitted by individuals and NGOs. Although the African Commission has determined fewer complaints in its first 30 years than other comparable regional human rights mechanisms, the Commission's jurisprudence has contributed to the development of human rights in several ways.

First, the Commission has clarified the meaning of vague rights protected by the African Charter through its decisions on communications, resolutions, principles and guidelines, and general comments. While the legal status of the Commission's recommendations is debateable, the Commission considers them to be legally binding. ${ }^{58}$ With the exception of Botswana, many States

53 Amnesty international and Others $v$ Sudan, Communication 48/90, 50/91, 52/91 \& 89/93, 13th Annual Activity report, (2000) AHRLR 297, para 31.

54 Constitutional Rights Project (in respect of Akamu and Others) $v$ Nigeria, Communication 6o/91, 8th Annual Activity Report, (2000) AHRLR 180, paras 9-11; Constitutional Rights Project (in respect of Lekwot \& Others) v Nigeria, Communication 87/93, 8th Annual Activity Report, (2000) AHRLR 183, paras 6-9; Civil Liberties Organisation v Nigeria, Communication 151/96, 13th Annual Activity Report, (2000) AHRLR 243, paras 11-16.

55 Most of these communications are available at the website of the African Commission $<$ http://www.achpr.org/communications/decisions/> and African Human Rights Case Law Analyser <http://caselaw.ihrda.org/body/acmhpr/>.

56 Ibid.

57 Democratic Republic of the Congo $v$ Burundi, Rwanda and Uganda, Communication 227/99, 2oth Activity Report, (2004) AHRLR 19.

58 See e.g. Jawara v Gambia, (n 47); Legal Resources Foundation v Zambia, Communication 211/98, 14th Annual Activity Report, (2001) AHRLR 84, paras 61-62; International Pen, Constitutional Rights Project, Civil Liberties Organisations and Interights (on behalf of Ken 
have never questioned or challenged the legal status of the African Commission's recommendations. 59

Second, the Commission has clarified that some rights not explicitly protected by the African Charter are implied in other rights protected in the Charter. For example, although the African Charter does not contain an explicit protection of the right to adequate housing, the Commission noted that the combined effect of Articles 14 (the right to property), 16 (the right to enjoy the best attainable state of mental and physical health) and 18(1) (the protection accorded to the family) of the African Charter 'reads into the African Charter a right to shelter or housing' and the right to food. ${ }^{60}$ Under this approach several internationally recognised human rights not explicitly protected by the African Charter (e.g. privacy, adequate food, water, sanitation, housing, and social security) can be read into the Charter.

Third, the Commission has clarified the scope of State obligations under the African Charter to respect, protect and fulfil human rights in accordance with Articles 60 and 61 of the African Charter or 'international human rights instruments and practices' (Scanlen and Holdreness $v$ Zimbabwe, Communication 297/05, 3 April 2009, para 115). The African Charter provides in Article 1 that States parties shall 'recognize the rights, duties and freedoms' enshrined in the Charter and 'shall undertake to adopt legislative or other measures to give effect to them'. On this basis the Commission's jurisprudence has confirmed that States are obliged to protect individuals and groups against violations by non-State (private) actors. ${ }^{61}$ This requires adopting and enforcing appropriate legislation and policy protecting rights recognised in the African Charter. ${ }^{62}$

Saro-Wira) v Nigeria, Communications 137/94, 139/94, 154/96, 161/97, 12th Annual Activity Report, (2000) AHRLR 212, paras 113 and 116; Constitutional Rights Project (in respect of Zamani Lekwot and six others) v Nigeria, (n 54).

59 Kenneth Good v Republic of Botswana, Communication 313/05, 28th Activity Report. In its Combined 32nd and 33rd Activity Report, Ex.CL/782(XXII) Rev.2 (2013) the African Commission noted in para 24 that: 'Through Diplomatic Note Ref: 10/12 BEA5/21 C VIII (4) Ам в of 23 March 2012, the Republic of Botswana unequivocally stated the following: "the Government has made its position clear; that it is not bound by the decision of the Commission."'

6o SERAC v Nigeria, (n 6), paras, 6o, 64-67. The African Women's Protocol (n 17), Arts 15 and 16 specifically protect women's right to 'food security' and to 'adequate housing'.

61 Ibid, paras $57^{-58}$.

62 See e.g. Constitution of the People's Republic of Benin, Art 7 'The rights and duties proclaimed and guaranteed by the African Charter on Human and Peoples' Rights adopted in 1981 by the Organization of African Unity and ratified by Bénin on January 20, 1986 shall be an integral part of the present Constitution and of Béninese law.' See also the African 
Thus, a State's failure to ensure that the rights in the Charter are not violated constitutes a violation 'even if the state or its agents are not the immediate cause of the violation'.63 The Commission has also clarified the responsibility of non-state actors not to violate human rights. For instance, with respect to the right to adequate food the Commission has called on 'non-state actors involved in conflicts to allow unhindered access to humanitarian organisations to provide relief food and assistance to affected populations' ${ }^{64}$

Fourth, despite the lack of an express mandate on remedies in the African Charter, the Commission has made significant improvements in awarding remedies to victims of human rights violations. It should be noted that the Commission for many years placed overemphasis on promoting a 'positive dialogue' leading to amicable resolution of disputes in relation to individual communications. It was reluctant to award effective reparation (such as restitution, monetary compensation for loss suffered, rehabilitation, satisfaction and guarantees of non-repetition) proportional to the gravity of human rights violations. ${ }^{65}$ After finding (serious or massive) violations of the African Charter, the Commission either did not require any specific actions or measures to be taken by States to provide any remedy, ${ }^{66}$ made vague 'requests' to violating

Charter on Human and Peoples' Rights (Ratification and Enforcement) Act, Cap A9, Laws of the Federation of Nigeria, 1990.

63 Commission Nationale des Droits de L'Homme et des libertés v Chad, Communication 74/92, 9th Annual Activity Report, (2000) AHRLR 66, para 20.

64 Resolution on the Right to Food and Food Insecurity in Africa, ACHPR/Res. 374 (LX) 2017, 22 May 2017, para 4.

65 United Nations, Basic Principles and Guidelines on the Right to a Remedy and Reparation for Victims of Gross Violations of International Human Rights Law and Serious Violations of International Humanitarian Law, adopted and proclaimed by General Assembly resolution 6o/147 of 16 December 2005.

66 See e.g. Krischna Achutan (on behalf of Aleke Banda), Amnesty International on behalf of Orton and Vera Chirwa and Amnesty International on behalf of Orton and Vera Chirwa $v$ Malawi, Communication 64/92, 68/92, 78/92, 8th Annual Activity Report, (2000) AHRLR 144; Free Legal Assistance Group, Lawyers' Committee for Human Rights, Union interafricaine des droits de l'Homme, Les témoins de Jehovah v Zaire, Communications 25/89, 47/9o, 56/91, 100/93 (Joined), 1oth Annual Activity Report, (2000) AHRLR 74; Commission Nationale des Droits de L'Homme et des libertés v Chad, (n 63); Civil Liberties Organization v Nigeria, Communication 129/94, 9th Annual Activity Report, (2000) AHRLR 188; Amnesty International $v$ Zambia, Communication 212/98, 12th Annual Activity Report, (2000) AHRLR 325; Rights International v Nigeria, Communication 215/98, 13th Annual Activity Report, (2000) AHRLR 254; Forum of Conscience v Sierra Leone, Communication 223/98, 14th Annual Activity Report, (2000) AHRLR 293; and Huri-Laws v Nigeria, Communication 225/98, 14th Annual Activity Report, (2000) AHRLR 273. 
States to 'take the necessary steps to bring [domestic] law into conformity with the Charter'67 or to 'take the appropriate measures to remedy the situation'; 68 simply 'invites' the violating State to 'take all necessary steps to comply with its obligations under the Charter', 69 or it deferred to the States concerned to arrive at an 'amicable solution: ${ }^{70}$

For example, after deciding that the administrative detention of 517 nationals of West African States from Zambia for a period of over two months, the deprivation of their property and their subsequent detention constituted a violation of Articles 2, 7(1)(a), and 12(5) of the African Charter, the Commission resolved to 'continue efforts to pursue an amicable resolution in this case' instead of awarding compensation. ${ }^{71}$ Victims were not afforded an adequate remedy. In some limited communications in which the Commission accepted that victims suffered damages, it did not quantify the amount of damages but instead decided that damages be determined under relevant domestic law. ${ }^{72}$ For example in Embga Mekongo Louis v Cameroon, Mekongo, a citizen of Cameroon claimed damages in the sum of $\$ 105 \mathrm{~m}$ for alleged false imprisonment and miscarriage of justice. ${ }^{73}$ The Commission found that the author had been denied due process, contrary to Article 7 of African Charter and had in fact suffered damages. However, the Commission stated that it was 'unable to determine the amount of damages' and thus recommended that 'the quantum should be determined under the law of Cameroon. ${ }^{74}$

67 Media Rights Agenda, Constitutional Rights Project, Media Rights Agenda and Constitutional Rights Project v Nigeria, Communication 105/93-128/94-130/94-152/96 (joined), 12 Annual Activity Report, (2000) AHRLR 200; Constitutional Rights Project and Civil Liberties Organisation v Nigeria, Communications 143/95, 150/96, 13th Annual Activity Report, (2000) Ahrlr 235. See also Media Rights Agenda v Nigeria, Communication 224/98, 14th Annual Activity Report, (2000) AHRLR 262. After finding the Republic of Nigeria in violation of several provisions of the African Charter, the Commission simply urged 'Nigeria to bring its laws in conformity with the provisions of the Charter'.

68 Mouvement Ivoirien Des droits Humains $(M I D H) v$ Côte d'Ivoire, Communication 246/o2, 25th Annual Activity Report, (2008) AHRLR 75.

69 Constitutional Rights Project, CivilLiberties Organisation andMedia Rights Agendav Nigeria, Communication 140/94, 141/94, 145/95, 13 th Annual Activity Report, (2000) AHRLR 227.

70 See e.g. Rencontre Africaine pour la Défence des droits de l'Homme (RADDHO) v Zambia, Communication 71/92, 7th Annual Activity Report, (2000) AHRLR 321; John K Modise v Botswana (No 1), Communication 97/93, 10 Annual Activity Report, (2000) AHRLR 25.

$71 \quad$ RADDHO $v$ Zambia, ibid.

72 See Embga Mekongo Louis v Cameroon, Communication 59/91, 8th Annual Activity Report, (2000) AHRLR 56 .

73 Ibid.

74 Ibid, para 2. 
Although the Commission has not been consistent in its approach to remedies for human rights violations, in recent years (at least from 2003 onwards), the Commission has made some notable non-monetary recommendations. These include recommendations that complainants under detention (or civilians/journalists tried, convicted and sentenced by military tribunals) be released $^{75}$ or afforded a fair trial including access to family and legal representatives; ${ }^{76}$ annulment of government decrees ousting of judicial jurisdiction; ${ }^{77}$ amendment, repeal or adoption of domestic legislation and policy in conformity with a State's human rights 'obligations under the African Charter and other relevant international human rights instruments; ${ }^{78}$ ensure that immigration policies, measures and legislations do not have the effect of discriminating against persons on the basis of any prohibited ground (including race, colour, descent, national, ethnic origin, or any other status), and particularly take into account the vulnerability of women, children and asylum seekers; ${ }^{79}$ ensure that individuals are not deported/expelled to countries where they might face torture or their lives could be at risk; ${ }^{80}$ reinstatement of complainants 'unduly dismissed and/or forcibly retired workers' in former employment; ${ }^{81}$ rescission of deportation orders incompatible with

75 See e.g. Centre for Free Speech v Nigeria, Communication 206/97, 13th Annual Activity Report, (2000) AHRLR 250; Constitutional Rights Project v Nigeria, Communication 148/96, 13th Annual Activity Report, (2000) AHRLR 241 (the Commission urged Nigeria to release 11 soldiers of the Nigerian army found innocent).

76 Article $19 v$ Eritrea, Communication 275/2003, 22nd Activity Report, (2007) AHRLR 73.

77 Civil Liberties Organisation (in respect of the Nigerian Bar Association) v Nigeria, Communication 101/93, 8th Activity Report, (2000) AHRLR 186.

78 Curtis Francis Doebblerv Sudan, Communication 236/200o, 16th Annual Activity Report, (2003) AHRLR 153. See also Law Offices of Ghazi Suleiman v Sudan, Communication 228/99, 16th Annual Activity Report, (2003) AHRLR 144 the Commission requested 'the government of Sudan to amend its existing laws to provide for de jure protection of the human rights to freedom of expression, assembly, association and movement'.

79 Institute for Human Rights and Development in Africa (on behalf of Esmaila Connateh \& ${ }_{13}$ Others) $v$ Republic of Angola, Communication 292/2004, 24th Activity Report, (2008) AHRLR 43, para 87 .

8 Ibid.

81 Annette Pagnoulle (on behalf of Abdoulaye Mazou) v Cameroon, Communication 39/9o, 1oth Annual Activity Report, (2000) AHRLR 57; Malawi Africa Association, Amnesty International, Ms Sarr Diop, Union interafricaine des droits de l'Homme and RADDHO, Collectif des veuves et ayantsDroit, Association mauritanienne des droits de l'Homme v Mauritania, Communications 54/91, 61/91, 96/93, 98/93, 164/97,196/97, and 210/98, 13th Annual Activity Report, (2000) AHRLR 149. 
the African Charter; ${ }^{82}$ restoration of property rights; ${ }^{83}$ provision of 'adequate medical care and material care for persons suffering from mental health problems'; ${ }^{84}$ equitable allocation of national projects; ${ }^{85}$ lifting press bans; ${ }^{86}$ abolition of corporal punishments such as the penalty of lashes; ${ }^{87}$ conduct prompt, impartial, and effective official investigations into abuses of human rights, identify and prosecute those responsible for the human rights violations; ${ }^{88}$ the rehabilitation of a State's economic and social infrastructure such as education, health, water, and agricultural services; ${ }^{89}$ establish 'objective, transparent and non-discriminatory criteria' for determining citizenship; ${ }^{90}$ and take measures to ensure that evictions are carried out in accordance with international human rights standards. ${ }^{91}$

In addition, the Commission has acknowledged the significance of monetary awards, acknowledging the need for 'just and adequate' or 'fair and equitable' compensation, to victims of human rights violations

82 Zimbabwe Lawyers for Human Rights and Institute for Human Rights and Development in Africa (on behalf of Andrew Barclay Meldrum) v Zimbabwe, Communication 294/04, 13th Annual Activity Report, para 121(b) the Commission recommended that Zimbabwe should: 'Rescind the deportation orders against Mr Andrew Meldrum, so that he can return to Zimbabwe, if he so wishes, being a person who had permanent residence status prior to his deportation'.

83 Mouvement Ivoirien de droits de l'Homme (MIDH) [Ivorian Human Rights Movement] v Côte d'Ivoire, Communication 262/o2, 26th Activity Report, (2008) AHRLR 62.

84 Purohit and Moore $v$ The Gambia, Communication 241/2001, 16th Annual Activity Report, (2003) A HRLR 96.

85 Kevin Mgwanga Gunme et al. v Cameroon, Communication 266/2003, 26th Activity Report, (2009) AHRLR 9, para 215(4) the Commission recommended that Cameroon allocates 'national projects, equitably throughout the country, including Northwest and Southwest Cameroon, in accordance with economic viability as well as regional balance'.

86 Article $19 v$ Eritrea, $\left(\mathrm{n}_{76}\right)$.

87 Curtis Francis Doebbler v Sudan, Communication 236/2000, 16th Annual Activity Report, (2003) AHRLR 153.

88 Movement Burkinabé des Droits de l'Homme et des Peuples v Burkina Faso, Communication 204/97, 14th Annual Activity Report, (2001) A HRLR 51; Sudan Human Rights Organisation $\&$ Centre on Housing Rights and Evictions (COHRE) v Sudan, Communication 279/2003 and 296/2005, 28th Activity Report, (2009) AHRLR 153, para 229.

89 Sudan Human Rights Organisation $v$ Sudan, ibid.

90 The Nubian Community in Kenya $v$ The Republic of Kenya, Communication 317/2006, 17 th Extraordinary Session, 19-28 February 2015, <http://www.achpr.org/files/sessions/17th-eo/ comunications/317.06/communication_317.06_eng.pdf>, para 171 .

$91 \quad$ Ibid. 
against several violating States including Benin, ${ }^{92}$ Botswana, ${ }^{93}$ Cameroon, ${ }^{94}$ Congo, ${ }^{95}$ Democratic Republic of Congo (DRC), ${ }^{96}$ Eritrea, ${ }^{97}$

92 Odjouoriby Cossi Paulv Benin, Communication 199/97, 17th Annual Activity Report, (2004) AHRLR 15, the Commission found the Republic of Benin in violation of Article 7(1)(d) of the African Charter and urged 'the Republic of Benin to take the necessary steps to pay appropriate compensation for damages suffered by Mr Odjouoriby Cossi Paul due to the unduly prolonged proceedings in the processing of his case'.

93 Kenneth Goodv Republic of Botswana, (n 59) paras 243-244 the Commission recommended that Botswana provides 'adequate compensation' to the victim for the loss and cost he has incurred as a result of violations of Articles 1, 2, 7(1)(a), 9, 12(4) and 18(1) and 18(2) of the African Charter. The Commission observed that compensation should include but not be limited to 'remuneration and benefits he lost as a result of his expulsion, and legal costs he incurred during litigation in domestic courts and before the African Commission'.

94 Kevin Mgwanga Gunme et al. $v$ Cameroon, Communication 266/2003, 26th Activity Report, (2009) AHRLR 9, para 215(1)(5) the Commission recommended that the Government of Cameroon 'pays compensation to companies in Northwest and Southwest Cameroon, which suffered as a result of discriminatory treatment by banks'. See also Association of Victims of Post Electoral Violence \& INTERIGHTS v Cameroon, Communication 272/2003, 27th Activity Report, (2009) AHRLR 47, para 138 the Commission recommended that the State of Cameroon: 'Pursue its commitment to give fair and equitable compensation to the victims and without delay, to pay fair and equitable compensation for the prejudices suffered by the victims or their beneficiaries' and that 'the amount of compensation for the damages and interest be fixed in accordance with applicable laws'.

95 Antoine Bissangou v Republic of Congo, Communication 253/2002, 21st Annual Activity Report, (2006) AHRLR 80, the Commission found the Republic of Congo in violation of Article 3, 7 and 14 of the African Charter and requested the Republic of Congo to 'compensate the Complainant as required by paying him the amount fixed by the High Court of Brazzaville, namely the global amount of 195,037,000 FCFA equivalent to 297,333.00 Euros' and to 'pay compensation for the loss suffered by the complainant, the amount of which shall be determined in accordance with Congolese legislation'.

96 Marcel Wetsh'okonda Koso and others $v$ Democratic Republic of Congo, Communication 281/2003, 26th Activity Report, (2008) AHRLR 93, paras 94 and 97 the Commission found that the DRC violated the relevant Articles 7(a), (b), (d ) and 26 of the African Charter and urged the Government of the DRC to grant the victims, the five civilians who had been tried and sentenced to death by Military Tribunal for the theft of oil drums belonging to the military, a 'fair and equitable amount as compensation for the moral wrong suffered'.

97 Liesbeth Zegveld and Mussie Ephrem v Eritrea, Communication 250/2002, 17th Annual Activity Report, (2003) AHRLR 84, the Commission found Eritrea in violation of Articles 2, 6, 7(1) and 9(2) of the African Charter and urged Eritrea to 'order the immediate release of the 11 detainees' and recommended that Eritrea compensates the 11 detainees. See also Article $19 v$ Eritrea, $\left(\mathrm{n}_{76}\right)$, the Commission found Eritrea in violation of Articles 1, 5, 6, 7(1), 9 and 18 of the African Charter, urged the government of Eritrea to 'release or to bring to a speedy and fair trial the 18 journalists detained since September 2001, and to lift the 
Guinea, ${ }^{98}$ Kenya, ${ }^{99}$ Mauritania, ${ }^{100}$ Sudan, ${ }^{101}$ and Zimbabwe. ${ }^{102}$ These examples provide a basis to develop a coherent approach to remedies. In some communications the Commission has recommended that respondent States report to the Commission on the measures taken and/or obstacles faced in the implementation of the Commission's recommendations. This is required within a

ban on the press'; recommended that the detainees be granted immediate access to their families and legal representatives; and that the government of Eritrea 'takes appropriate measures to ensure payment of compensation to the detainees'.

98 African Institute for Human Rights and Development (on behalf of Sierra Leonean Refugees in Guinea) $v$ Republic of Guinea, Communication 249/2002, 20th Activity Report, (2004) AHRLR 57, the Commission found the Republic of Guinea in violation of Articles 2, 4, 5 , 12(5) and 14 of the African Charter and Article 4 of the OAU Convention Governing the Specific Aspects of Refugees in Africa. It recommended that 'a Joint Commission of the Sierra Leonean and the Guinean governments be established to assess the losses by various victims with a view to compensate the victims'.

99 Centre for Minority Rights Development (Kenya) and Minority Rights Group International on behalf of Endorois Welfare Council v Kenya, Communication 276/2003, 27th Activity Report, (2009) AHRLR 75 (Endorois), the Commission recognised indigenous peoples' rights over traditionally owned land and their right to development under the African Charter. It found Kenya in violations of Articles 1, 8, 14, 17, 21 and 22 of the African Charter and recommended that the Endorios be paid by Kenya 'adequate compensation to the community for all the loss suffered' as a result of their displacement from their ancestral lands.

100 INTERIGHTS, Institute for Human Rights and Development in Africa, and Association Mauritanienne des Droits de l'Homme v Mauritania, Communication 373/2006, 28th Activity Report, (2010) AHRLR 90, paras 65-66, where on review, the Commission found that Mauritania violated Articles 1 and 14 of the African Charter, and recommended that the respondent State should pay 'adequate compensation' to the victim for the loss suffered.

101 Sudan Human Rights Organisation v Sudan, (n 88), para 229(4). The Commission recommended that Sudan 'take measures to ensure that the victims of human rights abuses are given effective remedies, including restitution and compensation'.

102 Zimbabwe Human Rights NGO Forum v Zimbabwe, Communication 245/2002, 21st Activity Report, (2006) AHRLR 128, the Commission held that Zimbabwe was in violation of Articles 1 and 7(1) of the African Charter and called upon Zimbabwe to 'establish a Commission of Inquiry to investigate the causes of the violence which took place from February to June 2000 and bring those responsible for the violence to justice, and identify victims of the violence in order to provide them with just and adequate compensation'. See also Zimbabwe Lawyers for Human Rights \& Associated Newspapers of Zimbabwe $(A N Z) v$ Republic of Zimbabwe, Communication 284/2003, 26th Activity Report, (2009) AHRLR 325, the Commission recommended that Zimbabwe 'provides adequate compensation' to the complainants for the loss they incurred as a result of violations of Articles 1, $9(2), 14$ and 15 of the African Charter. 
certain period of time depending on the nature of violations found and remedies awarded (e.g. 90 days or 3 months, ${ }^{103} 180$ days or 6 months, ${ }^{104}$ or during the presentation of a State's 'next periodic report' in terms of Article 62 of the African Charter ${ }^{105}$ from the date of notification.

Article 1 of the African Charter requires States Parties to 'recognise the rights, duties and freedoms enshrined in the Charter' and to 'undertake to adopt legislative or other measures to give effect to them'. This includes undertaking measures to give effect to the recommendations of the supervisory mechanisms of the African Charter including the African Commission. Do States implement adverse decisions or recommendations made by the African Commission in order to ensure that States are in compliance with their obligations under the African Charter? In other words, do States undertake legislative or other appropriate measures (e.g. through judicial decisions, administrative actions, or executive decrees) to give effect to the Commission's recommendations?

There are examples showing the influence of the African Charter ${ }^{106}$ and the African Commission's case law on African judiciaries as a guide to the interpretation and application of national law. This is partly because 'there is a prima facie presumption that the legislature does not intend to act in breach of international law, including treaty provisions' as interpreted by relevant

103 See Resolution on the Importance of the Implementation of the Recommendations of the African Commission on Human and Peoples' Rights by States Parties, ACHPR/Res 97 (2006), 29 November 2006; Endorois, (n 99), Recommendations 1(g); Zimbabwe Lawyers, Communication 294/04, (n 82), para 121(e).

104 See Rules of Procedure of the African Commission (2010), Rule 112(2) 'In the event of a decision against a State Party, the parties shall inform the Commission in writing, within one hundred and eighty (180) days of being informed of the decision in accordance with paragraph one, of all measures, if any, taken or being taken by the State Party to implement the decision of the Commission'. See also INTERIGHTS, Communication 373/2006, (n 100), para 66(3); The Nubian Community in Kenya v The Republic of Kenya, Communication 317/2006, (n 9o), para 171.

105 Zimbabwe Human Rights NGO Forum v Zimbabwe, Communication 245/2002, (n 102); Interights et al. (on behalf of Mariette Sonjaleen Bosch) $v$ Botswana, Communication 240/2001, 17th Annual Activity Report, (2003) AHRLR 55; Legal Resources Foundation v Zambia, Communication 211/98, 14th Annual Activity Report, (2001) AHRLR 84; Purohit and Moore v The Gambia, Communication 241/2001, 16th Annual Activity Report, (2003) AHRLR 96.

106 See e.g. Mary Rono v Jane and William Rono, Court of Appeal Civil Appeal 66 of 2002, (Kenya Court of Appeal at Eldoret, 29 April 2005), (2005) A HRLR 107. The Court relied on Article 18(3) of the African Charter which obliges State parties to 'ensure the elimination of every discrimination against women and also ensure the protection of the rights of women and the child as stipulated in international declarations and conventions'. 
bodies. ${ }^{107}$ Some domestic courts have relied on the African Charter and African Commission's case law to find violations of human rights. Examples include cases of discrimination on the basis sexual orientation or sex. In 2015 the High Court of Kenya in Eric Gitari case ${ }^{108}$ extensively relied, inter alia, on the Article 10 of the African Charter, decisions of the African Commission on freedom of association ${ }^{109}$ and the Commission's resolution on the Right to Freedom of Association 110 to protect 'sexual minorities' in Kenya from non-discrimination on the basis of their actual or perceived sexual orientation or gender-identity. The Court found that non-registration of a NGO that promoted rights of lesbian, gay, bisexual, transgender/transsexual, and intersex (LGBTI) persons living in Kenya violated the right to freedom of association guaranteed under Article 36 of the Constitution of Kenya (2010). ${ }^{111}$ Other domestic courts have relied on the African Charter to protect women's rights to equality and nondiscrimination, for example in inheritance on the grounds of sex. ${ }^{112}$

The African Charter and the Commission's case law has also been relied on by domestic courts to protect the right of access to an independent and impartial court, ${ }^{113}$ and the right to liberty and security of the person due to detention beyond constitutionally prescribed limit of 72 hours. ${ }^{114}$ At a national

107 Molefi Ts'epe $v$ The Independent Electoral Commission and Others, Civ No 11/05, (2005) AHRLR 136 (Court of Appeal of Lesotho, 30 June 2005) para 16.

108 Eric Gitariv Non-governmental Organisation Coordination Board and 4 Others, Petition 440 of 2013, [2015] eKLR (High Court of Kenya at Nairobi, 24 April 2015), <http://kenyalaw.org/ caselaw/cases/view/108412/>.

109 Ibid. The Court relied on the following:Jawara $v$ The Gambia (n 47); Amnesty International vZambia (n 66); Kazeem Aminuv Nigeria, Communication 205/97, (2000) AHRLR 258; Law Office of Ghazi Suleiman v Sudan (II) (n 43); Civil Liberties Organisation v Nigeria, (n 77).

110 Eric Gitari, (n 107), para 87.

111 Ibid, paras 79-83.

112 See e.g. Mary Rono v Jane and William Rono, Court of Appeal Civil Appeal 66 of 2002, (Kenya Court of Appeal at Eldoret, 29 April 2005), (2005) AHRLR 107. The Court relied on Article 18(3) of the African Charter which obliges State parties to 'ensure the elimination of every discrimination against women and also ensure the protection of the rights of women and the child as stipulated in international declarations and conventions'. See also Molefi Ts'epe $v$ The Independent Electoral Commission and Others, (n 107) para 20.

113 See e.g. Ousman Sabally $v$ Inspector General of Police and Others, Civil Reference 2/2001 (Supreme Court of The Gambia, 5 December 2001), (2002) AHRLR 87, referring to Article 7 of the African Charter and Constitutional Rights Project and Others v Nigeria Communication 145/95, (2000) AHRLR 227, paras 11-12.

114 Ajaratou Mariam Denton v Director General of National Intelligence Agency and Others, Civil HC 241/o6/MF/o87/F1, (High Court of The Gambia, 24 July 2006), (2006) AHRLR 241, referring to Article 6 of the African Charter and Jawara v The Gambia, (n 47), paras 57-59. 
level, civil society has used either the fact of submission of communications to the Commission or the Commission's findings to campaign for legal reform culminating in the repeal of decrees in violations of rights protected in the African Charter such as the right to a fair trial ${ }^{115}$ and freedom from arbitrary arrest. ${ }^{116}$

However, it should be noted that the implementation of, or State compliance with, the recommendations have generally remained very low. This is due to the lack of political will to implement the Commission's recommendations and inadequate 'follow up' or monitoring of the implementation of the Commission's recommendations, ${ }^{117}$ in terms of reporting, information-gathering, assessment and enforcement. ${ }^{118}$ Unsatisfactory follow up has been caused, at least in part, by the lack of a reliable mechanism to assess compliance and data on the implementation of all decisions, as well as insufficient funding to develop such a mechanism or data base. In 2017 the Commission observed:

The insufficient funding of the Commission from the member state budget also impedes the Commission's capacity to follow-up on implementation as it prevents the Commission from developing effective follow up of its findings during country visits, and recommendations arising from its findings, resulting in the overall weakening of the effectiveness of the Commission. ${ }^{119}$

Despite the absence of a provision in the African Charter on interim or provisional measures, the Commission Rules of Procedure grant the Commission power to grant provisional measures. ${ }^{120}$ States are required to report to the

115 The Constitutional Rights Project (in respect of Zamani Lekwot and Six Others) $v$ Nigeria, Communication 87/93, 8th Annual Activity Report, (2000) AHRLR 183.

116 International PEN, Constitutional Rights Project, Civil Liberties Organisation and Interights (on behalf of Ken Saro-Wiwa Jnr.) v Nigeria, Communications 137/94, 139/94, 154/96, 161/97, 12th Annual Activity Report, (2000) AHRLR 212.

117 For example, the recommendations contained in the following decisions had not been implemented at the time of writing: Gabriel Shumba v Zimbabwe, Communication 288/04; Endorois (n 99).

118 See Rachel Murray et al., 'Monitoring implementation of the decisions and judgments of the African Commission and Court on Human and Peoples' Rights' (2017) 1 African Human Rights Yearbook 150-166; African Commission Resolution 257 Calling on the Republic of Kenya to Implement the Endorois Decision, 5 November 2013, <http://www.achpr .org/sessions/54th/resolutions/257/>.

119 42nd Activity Report of the African Commission on Human and Peoples' Rights, <http:// www.achpr.org/files/activity-reports/42/42nd_activity_report_eng.pdf>, para 45 .

120 Rules of Procedure of the African Commission, (n 104), Rule 111. 
African Commission on measures taken to implement provisional measures. ${ }^{121}$ Importantly, the Commission has granted provisional measures (especially in the form of letters of appeal to the Heads of State urging their intervention pending the outcome of complaints before the Commission) in several cases. ${ }^{122}$ These include cases when an execution has been imminent, ${ }^{123}$ cases of arrest and detention of individuals without trial such as journalists ${ }^{124}$ and former governmental officials, ${ }^{125}$ and to prevent irreparable harm being caused to victims of alleged human rights violations (indigenous peoples). ${ }^{126}$ Although the Commission has held that the refusal to comply with provisional measures violates State parties obligation under Article 1 of the African Charter to 'undertake measures to give effect' to the provisions of the Charter, States have rarely complied with the Commission's requests for provisional measures or letters of urgent appeal regarding allegations of human rights violations in States. ${ }^{127}$ For example executions have been carried out by governments in violation of

\footnotetext{
121 Ibid, Rule 98(4).

122 See e.g. Shereen Said Hamd Bakhet v Arab Republic of Egypt, Communication 658/17; Ahmed Mustafa \& 5 Others (Represented by Justice for Human Rights \& AMAN Organisation) v Arab Republic of Egypt, Communication 659/17; Franck Diongo Shamba (represented by All4Rights) v Democratic Republic of Congo, Communication 652/17; Ahmed Abdul Wahab Al Khateeb v Arab Republic of Egypt, Communication 654/17; Les femmes de Lieke Lesole parties civiles dans l'affaire Basele Lututula, alias colonel Thom's et autres (représentées par Action Contre l'Impunité pour les Droits Humains) v République Démocratique du Congo, Communication 655/17; Anas Ahmed Khalifa v Arab Republic of Egypt, Communication 656/17; Andargachew Tsege and Others (Represented by Reprieve and REDRESS) $v$ The Federal Democratic Republic of Ethiopia, Communication 507/15.

123 Interights (on behalf of Safia Yakubu Husaini and Others) v Nigeria, Communication 269/2003, 18th Annual Activity Report (2004-2005); (2005) A HRLR 56. Ms Safiya Hussaini, a Nigerian woman and nursing mother, was sentenced to death by stoning by a so-called Sharia court in Gwadabawa, Sokoto state Nigeria, for an alleged crime of adultery.

124 Samuel Kofi Woods, ii and Kabineh M. Ja'neh v Liberia, Communication 256/2002, 17th Activity Report (2003-2004).

125 See e.g. Liesbeth Zegveld and Mussie Ephrem v Eritrea, Communication 250/2002, (2003) AHRLR 85 .

126 The Indigenous Peoples of the Lower Omo (Represented by Survival International Charitable Trust) v Ethiopia, Communication 419/2012.

127 International PEN, Constitutional Rights Project, Civil Liberties Organisation and Interights (on behalf of Ken Saro-Wiwa Jnr.) v Nigeria, Communication 137/94, 139/94, 154/96 and 161/97, 12 Annual Activity Report (1998-1999); (2000) AHRLR 212. See also 43rd Activity Report of the African Commission on Human and Peoples' Rights, <http://www.achpr.org/ files/activity-reports/43/43rd_activity_report_eng.pdf>, paras 23, 29-30; 42nd Activity Report of the African Commission On Human And Peoples' Rights, <http://www.achpr.org/ files/activity-reports/42/42nd_activity_report_eng.pdf>, paras $35^{-36}$.
} 
provisional measures to stay execution ${ }^{128}$ and using hanging, as a method of execution (which is 'inhuman and degrading') in violation of Article 5 of the African Charter. ${ }^{129}$

\section{Adoption of Resolutions, Principles/Guidelines, General Comments, Model Laws and Advisory Opinions}

Article 45(1)(b) of the African Charter mandates the Commission to 'formulate and lay down, principles and rules aimed at solving legal problems relating to human and peoples' rights and fundamental freedoms upon which African Governments may base their legislations' (emphasis added). Under this provision, the Commission (in collaboration with civil society including NGOs) ) $^{130}$ has adopted significant resolutions, declarations, principles/guidelines, and general comments to guide the interpretation and application of specific rights under the African Charter and other relevant human rights instruments in Africa and to ensure their coherent application to a range of situations, including their implementation at the domestic level. ${ }^{131}$ The Commission's resolutions could generally be classified into three categories namely thematic, administrative, and country-specific resolutions.

First, thematic resolutions elaborate in greater detail specific human right themes or particular substantive rights protected explicitly or implicitly protected in the Charter. Generally, they define obligations of states parties to the Charter in greater detail similar to the general comments of the UN treaty bodies. The Commission has passed a number of thematic resolutions and declarations covering a wide range of themes including the death penalty, ${ }^{132}$ indigenous peoples, the situation of women and children, the situation of

128 Ibid.

129 Interights \& Ditshwanelo $v$ The Republic of Botswana, Communication $319 / 06,57^{\text {th }}$ Ordinary Session of the African Commission, 4-18 November 2015, paras 24 and 87; African Commission, Press Release on the Execution of Joseph Poni Tselayarona, 21 February 2018, <http://www.achpr.org/press/2018/o2/d388/>. See also Republic v Mbushuu, [1994] 2 LRC 335 (High Court of Tanzania).

130 In November 2017, five hundred and fifteen (515) NGOs had Observer Status with the African Commission. See Final Communiqué of the 6ist Ordinary Session of the African Commission on Human and Peoples' Rights Banjul, The Gambia 1st - 15 November 2017, para 41.

131 The Commission's resolutions, declarations, guidelines and principles are available at $<$ http://www.achpr.org/instruments/>.

132 Resolution Calling on State Parties to Observe a Moratorium on the Death Penalty, 24 November 2008. 
human rights defenders in Africa, ${ }^{133}$ Economic, Social and Cultural Rights in Africa, ${ }^{134}$ right to education, maternal mortality, HIV/AIDS, the right to food and food insecurity in Africa, ${ }^{135}$ electoral process and good governance, prisons in Africa, torture, independence of the judiciary, contemporary forms of slavery, freedom of association, freedom of expression, ${ }^{136}$ fair trial, protection against human rights violations on the basis of one's real or imputed sexual orientation or gender identity, situation of Internally Displaced Persons in Africa, and the Importance of the Implementation of the Recommendations of the African Commission. ${ }^{137}$ The Commission has subsequently relied on its resolutions in its case law.

For example, in Interights $v$ Botswana, the Commission relied on its resolution on the death penalty to urge 'all states party to the African Charter on Human and Peoples' Rights to take all measures to refrain from exercising the death penalty'.138 Later, in November 2015, the Commission specifically urged Botswana 'to take all measures to comply with the Resolution urging State Parties to observe a Moratorium on the Death Penalty'139 and 'to take steps to abolish the death penalty'.140 Although several African States have not formally abolished the death penalty (including hanging as a method of execution), ${ }^{141}$ the application of the death penalty in practice has increasingly been restricted. For example under various laws of Uganda a broad array of

133 See Resolution on the Situation of Human Rights Defenders in Africa, Resolutions ACHPR/Res.119 (XXXXII) 07, ACHPR/Res.196 (L) 11, ACHPR/Res.273 (LV) 14, ACHPR/Res. 336 (XIX) 16, and ACHPR/Res. 376 (LX) 2017.

134 ACHPR/Res.73(XXXVi)04.

135 Resolution on the Right to Food and Food Insecurity in Africa, ACHPR/Res.374 (LX) 2017, 22 May 2017.

136 Declaration of Principles on Freedom of Expression in Africa, ACHPR/Res.62(XXXII)o2, 23 October 2002.

137 See African Commission, Resolutions, <http://www.achpr.org/resolutions/>.

${ }_{13} 8$ Interights et al. (on behalf of Mariette Sonjaleen Bosch) $v$ Botswana, Communication 240/2001, 17th Annual Activity Report (2003), (2003) AHRLR 55, para 52.

139 Interights \& Ditshwanelo $v$ The Republic of Botswana, Communication $319 / 06,57^{\text {th }}$ Ordinary Session of the African Commission, 4-18 November 2015, para 99(2).

140 Ibid, para 99(3).

141 See Death Penalty Wordwide, <http://www.deathpenaltyworldwide.org/>. In Lehlohonolo Bernard Kobediv The State, Criminal Appeal 25 of 2001, 2003 BWCA 22 (Court of Appeal of Botswana, 19 March 2003) held that Section 4 of the Botswana Constitution 1966, permitting deprivation of life in execution of a sentence of a court in respect of an offence under the law in force in Botswana of which one has been convicted, could not contravene Section 7 of the Constitution, prohibiting torture, inhumane or degrading punishment, since they both formed part of the same Constitution. 
crimes (including murder, aggravated robbery, treason and terrorism resulting in the death of a person) were punishable by a mandatory death penalty. ${ }^{142}$ In 2009 the Supreme Court of Uganda held that the various provisions of the laws of Uganda which prescribe a mandatory death sentence were unconstitutional. ${ }^{143}$ It further decided that the mandatorily imposed death sentences received by the vast majority of more than 400 appellants in this case should be commuted to life imprisonment. ${ }^{144}$ Several other African States (including Tanzania, Nigeria, Mauritania and Sudan) have commuted death sentences to life imprisonments. ${ }^{145}$ The judiciary in other African States is increasingly against the application of the death penalty for all crimes. This is clearly demonstrated in two decisions of the Constitutional Court of Benin. The first one was delivered on 4 August 2012 declaring that, due to Benin's accession to the Second Optional Protocol to the International Covenant on Civil and Political Rights, aiming at the abolition of the death penalty (ICCPR-OP2), 146 'no legal provision can now mention the death penalty' in Benin. ${ }^{147}$ The second one was delivered on 21 January 2016 stating that the entry into force of ICCPR-OP2, and its accession by the Republic of Benin, ${ }^{148}$ 'now renders inoperative all legal provisions stipulating the death penalty as a punishment' and that 'no one can now be sentenced to capital punishment in Benin.' ${ }^{149}$ Accordingly the government of Benin commuted death sentences to life imprisonment. ${ }^{150}$

\footnotetext{
142 See Concluding observations of the Human Rights Committee, UN Doc CCPR/Co/80/UGA (4 May 2004), para 13.

143 See e.g. Attorney Generalv Susan Kigula \& 417 Others, Constitutional Appeal No 03 of 2006, [2009] U GSC 6 (21 January 2009).

144 Ibid.

145 43rd Activity Report of the African Commission on Human and Peoples' Rights, para 35 (xiii).

146 GA res. 44/128, annex, 44 UN GAOR Supp. (No. 49) at 207, UN Doc. A/44/49 (1989), entered into force 11 July 1991, Art 1 provides: '1. No one within the jurisdiction of a State Party to the present Protocol shall be executed. 2. Each State Party shall take all necessary measures to abolish the death penalty within its jurisdiction'.

147 Benin Constitutional Court Decision DCC 12-153 (4 August 2012), <http://www.cour -constitutionnelle-benin.org/doss_decisions/12153.pdf>. The Constitutional Court held that domestic legislative providing for the death penalty (Arts 685(2) and 793 Code of Criminal Procedure) inconsistent with Article 147 of the Constitution, which effectively gave the ICCPR-OP2 supremacy over the Code of Criminal Procedure. Article 147 of Benin's Constitution, (1990) provides that: 'Treaties or agreements lawfully ratified shall have, upon their publication, an authority superior to that of laws....

148 In 2012 Benin became the 75th State Party to the ICCPR-OP2.

149 Benin Constitutional Court Decision DCC 16-020, (21 January 2016), <http://www .cour-constitutionnelle-benin.org/doss_decisions/DCC\%2016-o2o.pdf>.

150 Amnesty International, Benin: Death Sentences of Fourteen Prisoners Commuted, AI Index: ACT 50/8015/2018, 9 March 2018.
} 
In addition, the Commission has adopted several guidelines on various human rights issues (including reporting; torture; fair trial; economic, social and cultural rights; arrest; terrorism; policing of assemblies; freedom of association and assembly; sexual violence; access to information and decriminalisation of petty offences)..$^{151}$ It has also adopted model laws ${ }^{152}$ and general comments on some human rights issues (including rights of women; ${ }^{153}$ the right to life; ${ }^{154}$ the right to redress for victims of torture; ${ }^{155}$ and ending child marriage). ${ }^{156}$ Through such documents the Commission has clarified the scope of State parties' obligations to respect, protect and fulfil human rights within a State's jurisdiction or otherwise where a State exercises effective authority, power, or control over either the perpetrator or the victim or exercises effective control over the territory on which the victim's rights are affected. It has also interpreted civil and political rights to contain aspects of economic, social and cultural rights.

151 See e.g. Guidelines for National Periodic Reports (1989); Resolution on Guidelines and Measures for the Prohibition and Prevention of Torture, Cruel, Inhuman or Degrading Treatment or Punishment in Africa (Robben Island Guidelines), (2002); Principles and Guidelines on the Right to Fair Trial and Legal Assistance in Africa, (2003); Principles and Guidelines on the Implementation of Economic, Social and Cultural Rights in the African Charter on Human and Peoples' Rights (2011); State Party Reporting Guidelines for Economic, Social and Cultural Rights in the African Charter on Human and Peoples' Rights (Tunis Reporting Guidelines) (2011); Guidelines on the Conditions of Arrest, Police Custody and Pre-Trial Detention in Africa (2015); Principles and Guidelines on Human and Peoples' Rights while Countering Terrorism in Africa (2015); and Guidelines for the Policing of Assemblies by Law Enforcement Officials (2017); Guidelines on Freedom of Association and Assembly in Africa (2017); Guidelines on Combating Sexual Violence and its Consequences in Africa (2017); The Draft Guidelines on Access to Information and Elections for Africa (2017); and Principles on the Decriminalisation of Petty Offences (2017).

152 See e.g. Model Law on Access to Information for Africa (2011), <http://www.achpr.org/ files/instruments/access-information/achpr_instr_model_law_access_to_information _2012_eng.pdf>.

153 General Comment No. 2 on Article 14.1 (a), (b), (c) and (f) and Article 14. 2 (a) and (c) of the Protocol to the African Charter on Human and Peoples' Rights on the Rights of Women in Africa (2014).

154 General Comment No. 3 on the African Charter on Human and Peoples' Rights: The Right to Life (Article 4), (2015).

155 General Comment No. 4 on the African Charter on Human and Peoples' Rights: The Right to Redress for Victims of Torture and Other Cruel, Inhuman or Degrading Punishment or Treatment (Article 5), (2017).

${ }_{15} 6$ Joint General Comment of the African Commission on Human and Peoples' Rights (ACHPR) and the African Committee of Experts on the Rights and Welfare of the Child (ACERWC) on Ending Child Marriage (2017). 
For example, with respect to the right to life under the African Charter, ${ }^{157}$ the Commission stated that the African Charter envisages 'the protection not only of life in a narrow sense, but of dignified life'. ${ }^{158}$ This requires the 'realisation of all human rights' recognised in the African Charter, including civil, political, economic, social and cultural rights and peoples' rights, particularly the right to peace. ${ }^{159}$ It follows that in certain circumstances violations of economic, social and cultural rights (death resulting, for example, from the arbitrary denial of available healthcare, food, water or housing) may entail violations of the right to life. ${ }^{160}$

This broad understanding of the right to life imposes on States obligations to 'respect, protect, promote and fulfil' the right to life. ${ }^{161}$ First, States are obliged to 'prevent arbitrary deprivations of life' caused by State agents. ${ }^{162}$ Second, States are obliged to protect individuals and groups from real and immediate risks to their lives caused either by actions or inactions of third parties/other private individuals or entities, including corporations. ${ }^{163}$ The obligation to protect life entails both actions to preventive steps to 'preserve and protect the natural environment and humanitarian responses to natural disasters, famines, outbreaks of infectious diseases, or other emergencies. ${ }^{164}$ It also includes State responsibility to 'address more chronic yet pervasive threats to life, for example with respect to preventable maternal mortality, by establishing functioning health systems ${ }^{165}$ and eliminating discriminatory laws and practices which impact on individuals' and groups' ability to seek healthcare. ${ }^{166}$ The third obligation requires States to 'conduct prompt, impartial, thorough and transparent investigations' into any killings or deprivations of life that may have occurred, holding those responsible to account and providing for an effective remedy

157 Article 4 of the African Charter protects the right to life as follows: 'Human beings are inviolable. Every human being shall be entitled to respect for his life and the integrity of his person. No one may be arbitrarily deprived of this right.' The right to life is also protected in other African legal instruments e.g. Article 4 of the Protocol to the African Charter on Human and Peoples' Rights on the Rights of Women in Africa; and Articles 5 and 30 of the African Charter on the Rights and Welfare of the Child.

${ }_{158}$ General Comment No. 3, para 3 (emphasis added).

159 Ibid, para 6.

160 Ibid, para 43 .

161 Ibid, para 7.

162 Ibid, para 2.

163 Ibid, paras 2, 3, 41 .

164 Ibid, paras 3 and 41.

165 Ibid.

166 Ibid, para 42. 
and reparation for the victim or victims, including, where appropriate, their immediate family and dependents.' ${ }^{167}$ It follows from the foregoing that a 'State can be held responsible for killings by non-State actors if it approves, supports or acquiesces in those acts or if it fails to exercise due diligence to prevent such killings or to ensure proper investigation and accountability' 168

Second, administrative resolutions deal with the Commission's procedures, internal mechanisms and relationship between the Commission and other organs of the $\mathrm{AU}$, intergovernmental organisations, national human rights institutions (NHRIs) and NG Os. Some of the Commission's administrative resolutions include resolutions on the appointment and mandate of special rapporteurs and working groups, resolutions on the criteria for grant of observer status to NGOS and affiliate status to NHRIs, and the resolution on the protection of the name, acronym and logo of the Commission.

Third, country-specific resolutions address pertinent human rights concerns in member states. This category of resolution has proven very useful whenever there are widespread violations in a member state but no individual, NGO or state has submitted any communications to the Commission in respect of those violations. The Commission has passed specific resolutions to address the human rights situation in many African States including Sudan, Uganda, Zimbabwe, Ethiopia, Eritrea, Somalia, Kenya, DRC, Côte d'Ivoire, Comoros, Libya, Tunisia, Guinea Bissau, Liberia, Burundi, and Rwanda.

Finally, the African Charter grants mandate to the African Commission to give its 'views or make recommendations to the Governments' 169 and to 'interpret all the provisions of the [African] Charter' at the request of a State party, an institution of the AU or an African Organisation recognised by the AU. ${ }^{170}$ On this basis, the Commission can provide advisory opinions on human rights issues in Africa. While the Commission has not issued several advisory opinions, it issued an important advisory opinion in 2007 on indigenous peoples' rights, one of the most marginalised indigenous communities in Africa. ${ }^{171}$ This alleviated concerns African States had about the 'political, economic, social and constitutional implications' of the adoption of the UN Declaration on

167 Ibid, para 7 .

168 Ibid, para 9 .

169 African Charter, (n 11), Art 45(1)(a).

$170 \quad$ Ibid, Art 45(3).

171 See Advisory Opinion of the African Commission on Human and Peoples' Rights on the United Nations Declaration on the Rights of Indigenous Peoples, (2007), <http://www .achpr.org/files/special-mechanisms/indigenous-populations/un_advisory_opinion_idp _eng.pdf >. 
the Rights of Indigenous Peoples on the African continent. ${ }^{172}$ Following the African Commission's opinion, no African State voted against the adoption of the Declaration. ${ }^{173}$ Since then there has been increased recognition of indigenous peoples rights in Africa. This is partly reflected in litigation and emerging African jurisprudence (by the African Commission ${ }^{174}$ and national courts) ${ }^{175}$ on issues that are essential to indigenous peoples rights in Africa such as nondiscrimination, self-identification, land rights and development. ${ }^{176}$

(iv) Special Rapporteurs, Working Groups and Committees

Rule 23 (1) of the Commission's Rules of Procedure provides that: 'The Commission may create subsidiary mechanisms such as special rapporteurs, committees and working groups'. From mid-19gos the Commission has appointed various Special Rapporteurs (normally members of the Commission) and working groups (some of which include members outside the Commission) to deal with thematic human rights issues. These include the Special Rapporteur on Death Penalty, Extrajudicial, Summary or Arbitrary Killings in Africa; Freedom of Expression and Access to Information in Africa; the Rights of Women in Africa; Human Rights Defenders in Africa; Prisons, Conditions of Detention and Policing in Africa; the Protection of the Rights of People Living with HIV and those at Risk, Vulnerable to and Affected by HIV; Communications; Indigenous Populations/Communities in Africa; Refugees, Asylum Seekers, Internally Displaced Persons and Migrants in Africa; Extractive Industries, Environment and Human Rights Violations in Africa; and the Prevention of

172 See United Nations Declaration on the Rights of Indigenous Peoples, A/REs/61/295, (2 October 2007); AU Decision on the United Nations Declaration on the Rights of Indigenous Peoples, AU Doc. Assembly/AU/Dec.141 (VIII), (30 January 2007).

173 The Declaration was adopted by the UN General Assembly by a majority of 143 States in favour, 4 votes against (Australia, Canada, New Zealand and the United States) and 11 abstentions (Azerbaijan, Bangladesh, Bhutan, Burundi, Colombia, Georgia, Kenya, Nigeria, Russian Federation, Samoa and Ukraine).

174 Endorois (n 99).

175 See e.g. Roy Sesana, Keiwa Setlhobogwa and 241 others $v$ the Attorney General of the Republic of Botswana, (High Court of Botswana, 2006); Matsipane Mosetlhanyene and Gakenyatsiwe Matsipane v the Attorney General, (High Court of Botswana, 27 January 2011); Alexkor Ltd and Another $v$ Richtersveld Community and Others 2004 (5) SA 46o (Constitutional Court of South Africa, 14 October 2003); Uganda Land Alliance, Ltd. v Uganda Wildlife Authourity, Misc Cause No 0001 of 2004 (High Court of Uganda at Mbale, Consent Judgment and Decree).

${ }_{17} 6$ Jérémie Gilbert, 'Litigating Indigenous Peoples' Rights in Africa: Potentials, Challenges and Limitations' (2017) 66 ICLQ 657 . 
Torture in Africa. ${ }^{177}$ Rapporteurs are also empowered to 'monitor the measures taken by the State Party to give effect to the Commission's recommendations on each Communication.' ${ }^{178}$

The Commission has also established Working Groups on various human rights issues including Indigenous Populations or Communities; Economic, Social and Cultural Rights in Africa; the Death Penalty; the Rights of Older Persons and Persons with Disabilities in Africa; and Extractive Industries, Environment and Human Rights Violations. ${ }^{179}$ Furthermore the Commission has established committees on issues such as the Prevention of Torture in Africa; the Protection of the Rights of People Living with HIV (PLHIV) and Those at Risk, Vulnerable to and Affected by HIV; and a Committee on Resolutions. ${ }^{180}$ The special rapporteurs, committees and working groups examine developments in areas covered by their mandates, under-take on-site visits and produce reports with recommendations to improve the protection of human rights in Africa. ${ }^{181}$ Some general comments were developed by the working groups. For example, General Comment 3 on the Right to life, which clarifies the scope of the right to life under the African Charter, was developed by the Working Group on the Death Penalty and Extrajudicial, Summary or Arbitrary Killings in Africa. ${ }^{182}$

\section{(v) Consideration of State Reports}

Under Article 62 of the African Charter each state party undertakes to submit every two years 'a report on the legislative or other measures' taken to give effect to the rights guaranteed by the African Charter. The Commission examines the report, conducts a 'constructive dialogue' with State representative concerned and adopts concluding observations (since 2001). Through concluding observations, the Commission has highlighted positive aspects and identified the factors/challenges restricting the enjoyment of human rights in many African States. Such factors include widespread poverty and unemployment;

\footnotetext{
177 Final Communiqué of the 61st Ordinary Session of the African Commission on Human and Peoples' Rights, Banjul, The Gambia, 1-15 November 2017, <http://www.achpr.org/ files/sessions/61st/info/communique61/61st_os_final_communique_eng.pdf >, para 43.

178 Rules of Procedure of the African Commission, (n 104), Rule 112(4).

179 African Commission on Human and Peoples' Rights, Special Mechanisms, <http://www .achpr.org/mechanisms/>.

180 Ibid.

181 See e.g. Report of the African Commission's Working Group of Experts on Indigenous Populations/Communities, Doc/os(XXXIV)/345 (2005).

182 General Comment No. 3 (n 154).
} 
harmful cultural practices and deeply entrenched prejudices, in particular against women, minorities and indigenous peoples; lack of human rights awareness; and conflict and political crises. ${ }^{183}$ The Commission has also made recommendations to States regarding the measures required to strengthen the enjoyment of human rights guaranteed by the African Charter, as well as other relevant regional and international human rights instruments. ${ }^{184}$ For example, the Commission has recommended that States take the 'necessary steps' to amend national Constitution to incorporate economic, social, cultural and environmental rights, ratify international human rights treaties such as the ICESCR, consider withdrawing reservations to human rights treaties, and institute a moratorium on the death penalty. ${ }^{185}$ Recent recommendations are more detailed commenting on specific rights and groups. ${ }^{186}$ The Commission requires States to inform it in the next periodic report, of the 'measures taken' to address issues of concern, and to 'ensure the effective implementation of the recommendations.' ${ }^{187}$

However, the ability of the African Commission to monitor State compliance with human rights obligations under the African Charter has been largely limited by the fact that most States have not taken their reporting obligations seriously. As a result, most reports have not been submitted on time. ${ }^{188}$ Some States have never submitted any report. ${ }^{189}$ Only a few States have complied with reporting obligations under Article 26 of the Protocol on the Rights of Women in Africa (Maputo Protocol). ${ }^{190}$

183 See e.g. African Commission, Concluding Observations and Recommendations on the Combined 3rd, 4th and 5th Periodic Report of the Republic of Togo, 18 April - 2 May 2012, paras 35-38; Concluding Observations and Recommendations on the Initial Report of the Islamic Republic of Mauritania, 2-16 May 2002, paras 9-10; Concluding Observations and Recommendations on the 5th Periodic Report of the Federal Republic of Nigeria, 4-18 November 2015, paras $54-58$.

184 See African Commission, State Reports and Concluding Observations, <http://www.achpr .org/states/reports-and-concluding-observations/>.

185 See e.g. African Commission, Concluding Observations and Recommendations on the Initial Periodic Report of the Republic of Botswana, 12-26 May 2010, paras 53-57.

186 See e.g. Concluding Observations on Nigeria (n 183), para 137.

187 Ibid, para 137 .

188 See 43rd Activity Report of the African Commission on Human and Peoples' Rights, $<$ http://www.achpr.org/files/activity-reports/43/43rd_activity_report_eng.pdf>, para 20.

189 Ibid. By the end of 2017 Comoros, Equatorial Guinea, Guinea Bissau, Sao Tome and Principe, Somalia and South Sudan had never submitted a single report.

190 Ibid, para 22. In 2017 only 9 States (Burkina Faso, DrC, Malawi, Nigeria, Namibia, Mauritania, Rwanda, Senegal, and South Africa) had complied with their reporting obligations. 
(vi) Referral of Communications to the African Court

The Commission is empowered to submit cases to the African Court. As show below, by March 2018 the Commission had referred a few cases only to the Court involving Libya and Kenya.

\section{African Court on Human and Peoples' Rights}

In 2006 the protective mandate of the African Commission was complemented by the African Court on Human and Peoples' Rights (African Court). ${ }^{191}$ Significantly, the material jurisdiction of the African Court extends to all 'human rights instrument[s]' ratified by relevant States. ${ }^{192}$ The Protocol establishing the African Court has not yet been ratified by all States parties to the African Charter. ${ }^{193}$ Cases may be submitted to the Court directly by individuals and NGOs or indirectly through the African Commission. ${ }^{194}$ If the court finds a violation of a human right, it is empowered to 'make appropriate orders to remedy the violation.' ${ }^{195}$ A remedy may be considered 'appropriate' if it is 'adequate, effective, promptly attributed, holistic and proportional to the gravity of the harm suffered.' ${ }^{196}$ This includes the payment of 'fair compensation' (whether provided in the form of money, goods or services) or adequate 'reparation' (restitution, reinstatement). ${ }^{197}$ Other possible remedies the Court may grant,

191 African Court Protocol, (n 22), Arts 5(1)(a), 6(1) \& (3), 8 and 33; Decision on the Election of Judges of the African Court on Human and Peoples' Rights, Assembly/AU/Dec.10o(VI). The first 11 judges were elected in January 2006, inaugurated on 2 July 2006 and the Court had its first session from 2 to 5 July 2006, in Banjul, The Gambia.

192 African Court Protocol, (n 22), Art 3(1).

193 By March 2018, only 30 (namely Algeria, Benin, Burkina Faso, Burundi, Cameroon, Chad, Côted'Ivoire, Comoros, Congo, Gabon, Gambia, Ghana, Kenya, Libya,Lesotho, Mali, Malawi, Mozambique, Mauritania, Mauritius, Nigeria, Niger, Rwanda, Sahrawi Arab Democratic Republic, South Africa, Senegal, Tanzania, Togo, Tunisia and Uganda) out of 55 AU member States had ratified the African Court Protocol.

194 African Court Protocol, (n 22), Art 5. Cases may also be submitted to the Court by State parties and African Intergovernmental Organisations but by 2018 no cases had been submitted by any State or Intergovernmental organisation.

195 African Court Protocol, (n 22), Art 27(1).

196 See Committee on the Elimination of Discrimination against Women, General Recommendation No. 33 on Women's Access toJustice, CEDAW/C/GC/33 (3 August 2015), para 19(b).

197 African Court Protocol, (n 22), Art 27(1). 
based on the practice of other human rights bodies, ${ }^{198}$ include rehabilitation (medical and psychological care and other social services); orders of investigations and prosecutions of perpetrators when human rights violations occur in conflict or post-conflict contexts; mandate institutional reforms, repeal discriminatory legislation and enact legislation providing for adequate sanctions, guarantees of non-repetition.

Judgments and orders of the Court in contentious proceedings are legally binding. Thus, States parties are required to 'comply with the judgment in any case to which they are parties within the time stipulated by the Court and to guarantee its execution.199 Execution of judgments is monitored by the Executive Council of the AU on behalf of the AU Assembly. ${ }^{200}$ The Assembly is empowered to impose sanctions or take 'other measures of a political or economic nature' against States that do not comply with the AU 'decisions'. ${ }^{201}$ Such decisions include the Court's judgments and orders of provisional measures.

The Court may also provide advisory opinions on 'any legal matter' relating to the African Charter or 'any other relevant human rights instruments' (e.g. other AU human rights treaties and UN human rights treaties) provided the matter does not relate to an application pending before the African Commission. ${ }^{202}$ The substantive scope of the Court's advisory opinions is limited to 'human rights instruments' only as opposed to instruments on other areas of 'public international law' such as instruments dealing with individual criminal responsibility for international crimes. ${ }^{203}$ Such opinions are provided at the request of a member State of the $\mathrm{AU}$, the $\mathrm{AU}$, any of its organs, or any 'African organisation' (either intergovernmental or non-governmental) recognised by the $\mathrm{AU}^{204}$ This recognition is achieved through the granting

198 Thomas M Antkowiak and Alejandra Gonza, The American Convention on Human Rights: Essential Rights (Oxford University Press, 2017) 285-306; James A Sweeney, 'The Right to Truth in Transitional Human Rights Jurisprudence' (2018) 67 ICLQ 353.

199 African Court Protocol, (n 22), Art 30.

$200 \quad$ Ibid, Arts 29(2) and 31.

201 Constitutive Act of the African Union, adopted in Lome, Togo by the Thirty-Sixth Ordinary Session of the Assembly of Heads of State and Government 11 July 2000 and entered into force 26 May 2001, Art 23(2).

202 Ibid, Art 4; The Pan African Lawyers' Union (PALU) and Southern African Litigation Centre $(S A L C)$, Request 2/2012, Order Striking Out Request (Similar Request at the African Commission, 15 March 2013).

203 Coalition for the International Criminal Court, Legal Defence \& Assistance Project (LEDAP), Civil Resource Development \& Documentation Center and Women Advocates Documentation Center, Request 1/2015 (Order Striking Out the Request, 29 November 2015), para 18.

204 African Court Protocol, (n 22), Art 4. 
of observer status with the AU or the signing of any Memorandum of Understanding between the $\mathrm{AU}$ and the NGOs. ${ }^{205}$ The Court has declined to give Advisory Opinions requested by African Organisations which do not meet this requirement. ${ }^{206}$

\subsection{Direct Access to the African Court by Individuals and NGOS}

This is the easiest way to access the Court without delays associated with the process of going through the Commission. The Court has received numerous cases mainly brought directly to it by individuals and NG Os after exhaustion of domestic remedies. ${ }^{207}$ The Court handed down its first decision on jurisdiction ('judgment') in 2009. ${ }^{208}$ It has since handed down some judgments on merits in which it found violations of the African Charter, ${ }^{209}$ or no violations. ${ }^{210}$ The Court has also found violations of other human rights instruments including

205 Request for Advisory Opinion by 1 . The Centre for Human Rights, University of Pretoria 2. Federation of Women Lawyers, Kenya 3. Women's Legal Centre 4. Women Advocates Research and Documentation Centre 5. Zimbabwe Women Lawyers Association, Request No 001/2016, Advisory Opinion 28 September 2017, para 48.

206 Ibid.

207 See African Court Cases at <http://www.african-court.org/en/index.php/cases >; African Court Protocol, (n 22), Art 6(2); African Charter, (n 11), Art 56. In March 2018, out of 161 applications filed before Court, 147 were brought by individuals, 11 by NGOs and 3 by the African Commission.

208 Michelot Yogogombaye $v$ The Republic of Senegal, Application 001/2008 (15 December 2009).

209 See e.g. Konatév Burkina Faso, Application 4/13 (Judgment, 5 December 2014); Abdoulaye Nikiema, Ernest Zongo, Blaise Ilboudo \& Burkinabe Human and Peoples' Rights Movement $v$ Burkina Faso, Application 13/11 (Judgment, 28 March 2014); Onyango Nganyi v Tanzania, Application 6/2013, (Judgment, 18 March 2016);Jonas $v$ Tanzania, Application 11/2015 (Judgment, 28 September 2017); Onyachi and Others $v$ Tanzania, Application 3/2015 (Judgment, 28 September 2017); African Commission on Human and Peoples' Rights v Kenya, Application 6/2012 (Judgment, 26 May 2017); Actions pour la protection des droits de l'homme (APDH) v Côte d'lvoire, Application 1/2014 (Judgment, 18 November 2016); Christopher Jonas $v$ United Republic of Tanzania, Application 011/2015 (Judgment, 28 September 2017); Kijiji Isiaga v United Republic of Tanzania, Application 032/2015 (Judgment, 21 March 2018); Anudo Ochieng Anudo v The United Republic of Tanzania, Application 012/2015 (Judgment, 22 March 2018); Nguza Viking (Babu Seya) and Johnson Nguza (Papi Kocha) $v$ United Republic of Tanzania, Application 0o6/2015 (Judgment, 23 March 2018).

210 Mtikila v Tanzania, Application 11/2011, (Judgment, 14 June 2013); Thomas $v$ Tanzania, Application 5/2013, (Judgment, 20 November 2015); Onyango Nganyi $v$ Tanzania, Application 6/2013, (Judgment, 18 March 2016); Abubakari v Tanzania, Application 7/2013, (Judgment, 3 June 2016). 
the UDHR and the ICCPR. ${ }^{211}$ For example, in Anudo Ochieng Anudov The United Republic of Tanzania, ${ }^{212}$ Tanzania annulled the applicant's passport (Tanzanian nationality), which he had, until then enjoyed, declared him an 'illegal immigrant' and expelled him from Tanzania, without the possibility of an appeal before a national court. The Court found that this constituted the violation of the applicant's right not to be arbitrarily deprived of his nationality in violation of Article 15(2) of the UDHR; the right not to be arbitrarily expelled from a State and violation of the right to judicial remedy (the right to have his cause heard by a judge) contrary to Article 7 of the African Charter and Article 14 of the lCCPR. ${ }^{213}$ It ordered Tanzania to take all the necessary steps to restore the applicant's rights, by allowing him to return to the national territory, ensure his protection and ordered Tanzania to amend its legislation to provide individuals with judicial remedies in the event of dispute over their citizenship. ${ }^{214}$

In addition, the Court has also issued orders mainly dismissing applications for failure to comply with the admissibility requirements under Article $5^{6}$ of the African Charter. These include the failure to exhaust domestic (local) remedies before commencing proceedings, ${ }^{215}$ or the failure to submit cases within a reasonable period from the time local remedies are exhausted. ${ }^{216}$ At the request of States concerned, the Court has clarified aspects of its orders to enable States to implement the Court's rulings. ${ }^{217}$

In its first decade of operation, the Court decided more contentious cases than other regional human rights courts during the corresponding period. ${ }^{218}$

211 See e.g. Konatév Burkina Faso, (n 209), para 176. The Court found, inter alia, a violation of Art 19 ICCPR.

212 Anudo Ochieng Anudov The United Republic of Tanzania, Application 012/2015 (Judgment, 22 March 2018) para 132.

213 Ibid, para 115 .

214 Ibid, para 132.

215 Rules of Court (2010), Rule 34(4); Fidèle Mulindahabi v Republic of Rwanda, Application 008/2017 (order, 28 September 2017); Diakitè Couple v Republic of Mali, Application oog/2016 (Judgment, 28 September 2017).

216 Jean-Claude Roger Gombert v Republic of Côte d'Ivoire, Application 038/2016 (22 March 2018).

217 See e.g., Urban Mkandawire v The Republic of Malawi, Application 3/2011, (Ruling on Application for Interpretation of Judgment, 28 March 2014); and Alex Thomas $v$ United Republic of Tanzania, Application 001/2017 for Interpretation of Judgment of 20 November 2015 (Judgment, 28 September 2017); Mohamed Abubakariv United Republic of Tanzania, Application 002/2017 for Interpretation of Judgment of 3 June 2016 (Judgment, 28 September 2017); Mariam Kouma and Ousmane Diabatè v Republic of Mali, Application 040/2016 (Judgment, 21 March 2018).

218 See Frans Viljoen, 'Understanding and Overcoming Challenges in Accessing the African Court on Human and Peoples' Rights' (2018) 67 ICLQ 63-98. 
However, in most cases it found that it lacked jurisdiction mainly because of the limitations placed on direct access to the Court by individuals and NGOS. It should be noted that the Court's personal jurisdiction (jurisdiction ratione personae) is limited to States parties to the African Charter and the African Court Protocol. ${ }^{219}$ Thus, cases brought against non-State parties to the African Charter and African Court's Protocol were unsuccessful. 220

Direct access to the Court by individuals and NGOs (to obtain a remedy or to be represented as a victim in a contentious case or to solicit an advisory opinion) is limited by the requirement for an optional declaration made by State concerned recognising the competence of the Court to receive cases from individuals and NGOs (with observer status before the African Commission). ${ }^{221}$ Since it is optional to submit such a declaration, a State may unilaterally withdraw it. ${ }^{222}$ Most States have not deposited this optional declaration. ${ }^{223}$ Accordingly the Court lacks jurisdiction to 'receive any petition' from individuals and NG Os involving any State Party which has not made such a declaration. For this reason, several cases brought against States (e.g. Algeria, Cameroon, Côte d'Ivoire, Gabon, Mozambique, Nigeria, Senegal, South Africa, Sudan and Tunisia) that had not made the optional declaration at the relevant time failed. ${ }^{224}$

219 In March 2018, 30 States had ratified the Protocol: Algeria, Benin, Burkina Faso, Burundi, Cameroon, Chad, Côte d'Ivoire, Comoros, Congo, Gabon, Gambia, Ghana, Kenya, Libya, Lesotho, Mali, Malawi, Mozambique, Mauritania, Mauritius, Nigeria, Niger, Rwanda, Sahrawi Arab Democratic Republic, South Africa, Senegal, Tanzania, Togo, Tunisia and Uganda.

220 Femi Falana $v$ African Union, Application 1/2011, (Judgment, 26 June 2012); Atabong Denis Atemnkeng v African Union, Application 14/2011 (Judgment, 15 March 2013); Youssef Ababou $v$ Kingdom of Morocco, Application 7/2011, (Decision on Jurisdiction, 2 September 2011). African Court Protocol, (n 22), Arts 5(3) and 34 (6).

222 Rwanda submitted its declaration in 2013 but submitted a notification of withdrawal on 1 March 2016. The withdrawal became effective on 1 March 2017. See Inbabire Victoire Umuhoza $v$ Rwanda, App 3/2014, Ruling on the Effects of the Withdrawal of the Declaration under Article 34(6) of the Protocol (3 June 2016), para 58: 'As far as unilateral acts are concerned, state sovereignty commands that states are free to commit themselves and that they retain discretion to withdraw their commitments'. Withdrawal is effective a year after a withdrawal notification has been deposited.

223 In March 2018, only 8 of the 30 States Parties to the Protocol had made the declaration recognising the competence of the Court to receive cases from individuals and NGOs (in alphabetical order): Benin (2016), Burkina Faso (1998), Côte d'Ivoire (2013), Ghana (2011), Mali (2010), Malawi (2008), Tanzania (2010) and Tunisia (2017).

224 Soufiane Ababou v Algeria, Application 2/2011; Ekollov Cameroon and Nigeria, Application 8/2011; Association Juristes d'Afrique pour la Bonne Gouvernance v Côte d'Ivoire, Application 6/2011; National Convention of Teachers Trade Union v Gabon, Application 12/2011; Daniel Amare and Mulugeta Amare v Mozambique and Mozambique Airlines, Application 5/2011; Ekollo M. Alexandre v Cameroon and Nigeria, Application 8/2011; Michelot Yogogombaye v 
To its credit, the Court has since 2011-2017 delivered several orders for provisional measures in cases of 'extreme gravity and urgency' and 'when necessary to avoid irreparable harm to persons' and 'necessary to adopt in the interest of the parties or of justice.225 The cases in which provisional measures were issued involved Burkina Faso, Kenya, Libya, Ghana, Rwanda and Tanzania. 226 Significantly, most orders of provisional measures in the period $2015^{-16}$ related to cases brought by individuals (convicted prisoners on death row) against Tanzania to refrain from executing the death penalty confirmed by relevant domestic courts pending the determination of their applications. ${ }^{227}$ The Court

Senegal, Application 1/2008; Delta International investments (SA), AGL De Lange and M. De Lange $v$ South Africa, Application 2/2012; Emmanuel Joseph Uko and others $v$ South Africa, Application 4/2012; Amir Adam Timan v Sudan, Application 5/2012; Baghdadi Ali Mahmoudiv Tunisia, Application 7/2012.

225 African Court Protocol, (n 22), Art 27(2); Rules of Court, (n 215), Rule 51(1).

226 See e.g. African Commission v Lybia (Bengazi), Application 4/2011, Order for Provisional Measures (25 March 2011); African Commission v Lybia (Saif Al-Islam Kadhafi), Application 2/2013, Order for Provisional Measures (15 March 2013); African Commission v Kenya (Ogiek), Application 6/2012, Order for Provisional Measures (15 March 2013); Konate v Burkina Faso, Application 4/2013, Order for Provisional Measures (4 October 2013); Guehi $v$ Tanzania, Application 1/2015, Order for Provisional Measures (18 March 2016); Rajabu and 4 others $v$ Tanzania, Application 7/2015, Order for Provisional Measures (8 March 2016); Alfred Agbesi Woyomev $v$ Republic of Ghana, Application 001/2017 (24 November 2017); Lèon Mugesera v Republic of Rwanda, Application 012/2017 (28 September 2017); and Dexter Eddie Johnson v Republic of Ghana, Application 016/2017 (28 September 2017).

227 See Order for Provisional Measures in the following cases: Armand Guehi v The United Republic of Tanzania, Application 001/2015 (18 March 2016); Ally Rajabu and 4 Others $v$ The United Republic of Tanzania, Application 007/2015(18 March 2016);John Lazarov The United Republic of Tanzania, Application 003/2016 (18 March 2016); Evodius Rutechura v The United Republic of Tanzania, Application 004/2016 (18 March 2016); Habiyalimana Augustino and Mburo Abdulkarim v The United Republic of Tanzania, Application 015/2016 (3 June 2016);Deogratius NicholausJeshiv The United Republic of Tanzania, Application 017/2016 (3 June 2016); Cosma Faustine $v$ The United Republic of Tanzania, Application 018/2016 (3 June 2016);Joseph Mukwano $v$ The United Republic of Tanzania, Application 021/2016 (3 June 2016); Amini Juma $v$ The United Republic of Tanzania, Application 024/2016 (3 June 2016); Dominick Damian v The United Republic of Tanzania, Application 048/2016 (18 November 2016); Chrizant John v The United Republic of Tanzania, Application 049/2016 (18 November 2016); Crospery Gabriel \& Ernest Mutakyawa $v$ The United Republic of Tanzania, Application 050/2016 (18 November 2016); Nzigiyimana Zabron v The United Republic of Tanzania, Application 051/2016 (18 November 2016); Marthine Chistian Msuguriv The United Republic of Tanzania, Application 052/2016 (18 November 2016); Oscar Josiah v The United Republic of Tanzania, Application 053/2016 (18 November 2016); Gozbert Henerico $v$ The United Republic of Tanzania, Application 056/2016; Mulokozi Anatori $v$ The United 
took the view that the risk of execution of the death penalty will jeopardise the enjoyment of the rights to life, fair trial, and freedom from inhuman or degrading treatment or punishment under Articles 3(2), 4 and 7(1)(c) of the African Charter, ${ }^{228}$ Article 14 of the ICCPR, ${ }^{229}$ and Articles 3 and 5 of the UDHR. ${ }^{230}$ In 2017 the Court granted provisional measures ordering a respondent State to allow a person in custody access to his lawyers, visit by his family members and access to medical care. ${ }^{231}$ It also granted provisional measures ordering a respondent State to stay the attachment and sale of the applicant's property until his application is heard and determined. ${ }^{232}$ Thus, provisional measures have been used to protect not only civil and political rights but also economic, social and cultural rights including ordering a State to provide a detained journalist with the 'medication and health care required'.233

\subsection{Indirect Access to the African Court through the African Commission's Referral of Communications to the African Court}

Rule 118 of the 2010 Commission's Rules of Procedure allows the Commission to submit cases to the African Court in respect of all States parties to the African Court Protocol under four circumstances: (i) where a State has not complied or is unwilling to comply with the Commission's recommendations; (ii) where a State has not complied with the Commission's request for provisional (interim/precautionary) measures; (iii) situations involving serious or massive violations of human rights; and (iv) if the Commission 'deems necessary' to refer a communication to the Court at any stage (Commission's admissibility and merits finding). ${ }^{234}$ In all these situations, the Commission

Republic of Tanzania, Application 057/2016 (18 November 2016), all available at <http:// www.african-court.org/en/index.php/59-list-of-cases-with-provisional-measures/1037 -list-of-cases-where-orders-for-provisional-measures-have-been-issued>.

228 See e.g. Crospery Gabriel \& Ernest Mutakyawa v United Republic of Tanzania, Application 050/2016 (18 November 2016), para 16.

229 Evodius Rutechura $v$ The United Republic of Tanzania, Application 004/2016 (18 March 2016), paras 16-17; Ally Rajabu and 4 Others $v$ The United Republic of Tanzania, Application 007/2015 (18 March 2016), paras 18-19; Armand Guehiv The United Republic of Tanzania, Application 001/2015 (18 March 2016), para 19-20.

230 Dexter Eddie Johnson v Republic of Ghana, Application 016/2017 (28 September 2017), para 17 .

231 Lèon Mugesera v Republic of Rwanda, Application 012/2017 (28 September 2017).

232 Alfred Agbesi Woyome v Republic of Ghana, Application oo1/2017 (24 November 2017).

233 Konate v Burkina Faso, Application 4/2013, Order for Provisional Measures (4 October 2013), para 23(ii).

234 See Rules of Procedure of the African Commission (n 104), Rule 118. 
represents the interest of one party to the dispute (the applicant) before the Court. However, the Court has discretion to hear 'any person' including the original complainants before the Commission (victims) and their representatives as well as amici curiae. ${ }^{235}$

\section{Referral of Non-compliance or Unwillingness to Comply with the} Commission's Recommendations

The African Commission 'may', at its discretion, submit a case to the African Court, where it 'considers that the State [party to the African Court Proto$\mathrm{col}$ ] has not complied or is unwilling to comply with its recommendations in respect of the communication' within the period specified. ${ }^{236}$ The aim is to enable the African Court to give legally binding judicial 'enforcement' to the quasi-judicial decisions of the African Commission where the State has failed or is unwilling to implement recommendations made by a quasi-judicial body (the Commission) in communications decided by the Commission on the merits. By March 2018, the African Commission had not yet referred to the Court cases decided on merits of alleged non-compliance with its recommendations. It is desirable to refer all cases of non-compliance to the Court, 'unless there is a reasoned decision by an absolute majority of members of the Commission to the contrary'237 The Commission did not refer States to the Court because most non-complying States in cases finalised by the Commission (Angola, Botswana, D RC, Ethiopia, Eritrea, Sudan, and Zimbabwe) in the period 2010-2018 had not accepted the jurisdiction of the African Court. In addition, the Commission was reluctant to make referrals to the Court in appropriate cases in which there was non-compliance, ${ }^{238}$ possibly to avoid a possibility of conflicting findings on the merits by the Court after reconsideration of the facts. ${ }^{239}$

235 Rules of Court, (n 215), Rules 29(3)(c) and 45(2); Court's Practice Directions (2012), paras 42-47; African Commission v Kenya (Ogiek), Application 6/2012, paras 27-29.

236 Rules of Court, ibid, Rule 118. Under Rule 112(2) States are required to inform the Commission of 'all measures, if any, taken or being taken by the State Party to implement the decision of the Commission' within 180 days of being informed of the decision.

237 See Rules of Procedure of the Inter-American Commission, (2009), <http://www.oas.org/ en/iachr/mandate/basics/rulesiachr.asp $>$, Rule 45(1).

238 See e.g. Endorois (n 99); African Commission Resolution 257 Resolution Calling on the Republic of Kenya to Implement the Endorois Decision, adopted on 5 November 2013, <http://www.achpr.org/sessions/54th/resolutions/257/>.

239 Rules of Court, (n 215), Rule 44. 
Referral of Non-compliance with the Commission's Request for Provisional (Interim) Measures

The Commission may, on its initiative or at the request of a party to the communication, 'request' that the State concerned adopt provisional measures to prevent irreparable harm to the victim or victims of the alleged violation as urgently as the situation demands. ${ }^{240}$ This may be done at any time after the receipt of a communication and before a determination on the merits. ${ }^{241}$ If the Commission considers that the State has not complied with the provisional measures requested, the Commission may refer the communication to the Court and inform the complainant and the State concerned. ${ }^{242}$ The referral is intended to transform the Commission's 'requests' for provisional measures into legally binding Court 'orders' of provisional measures. In a few cases of non-compliance with the Commission's 'requests' for provisional measures referred to the African Court, the Court ordered provisional measures of its own, ${ }^{243}$ and subsequently considered cases referred to it on the merits finding human rights violations. ${ }^{244}$

\section{Referral of Serious or Massive Violations of Human Rights}

The Commission may submit a communication (already pending before it) to the Court against a State party if in its view a 'situation' has come to its attention which constitutes 'one of serious or massive violations of human rights. ${ }^{245}$ The referral of Libya to the Court in 2011 represents an example of such a situation. The UN Security Council deplored 'the gross and systematic violation of human rights' in Libya particularly the widespread and systematic attacks against the civilian population. ${ }^{246}$ It is desirable to refer all situations of 'serious' or 'massive' violations of human rights to the Court in the future.

\footnotetext{
240 Rules of Procedure of the African Commission, (n 104), Rule 98.

241 Ibid.

242 Ibid, Rule $118(2)$.

243 African Commission (Saif Al-Islam Kadhafi) v Lybia, Application 2/2013, Order of Provisional Measures (15 March 2013); African Commission (Ogiek) v Kenya, Application 6/2012, Order for Provisional Measures (15 March 2013).

244 African Commission (Saif Al-Islam Gaddafi) v Lybia, Application 2/2013, Judgment (3 June 2015), the Court found that Libya had violated the fair trial rights of the detainee; African Commission v Kenya (Ogiek), Application 6/2012 (26 May 2017), the Court found that Kenya violated various provisions of the African Charter.

245 Rules of Procedure of the African Commission, (n 104), Rule 118(3); Rule 84(2); African Charter, (n 11), Article 58 .

246 UN Security Council Resolution 1970 (2011), S/RES/1970 (2011), 26 February 2011.
} 
(iv) Referral at 'any stage of the examination of a communication' Finally, the Commission may 'seize' the Court 'at any stage of the examination of a communication if it deems necessary'. ${ }^{247}$ This means that the Commission may refer cases to the Court before deciding communications before it on the merits. The referral may be made at 'any stage' even before deciding on the admissibility of the communication before the Commission. ${ }^{248}$ Such referrals should be made only if it is 'necessary' to do so, meaning that there must be pressing need for a binding order or judgment in response to a situation of extreme gravity and urgency. ${ }^{249}$

While there is much progress still to be made, the African Commission has greatly contributed to the regional protection of human rights in Africa. The Commission has exposed human rights violations in most authoritarian African States. Through its decisions on communications, it has developed human rights jurisprudence in Africa on several aspects consistent with the jurisprudence of other human rights bodies. ${ }^{250}$ These include jurisprudence on exhaustion of local remedies, State obligations concerning civil and political rights, economic, social and cultural rights as well as group rights such indigenous peoples' rights and the right to development. Nevertheless, the African Commission has only received and decided very few communications related to economic, social and cultural rights.

Initially, it was thought the Commission would be unable to hold States accountable for violations of human rights and to provide reparations to victims. However, over the years the Commission has confronted human rights violations through its decisions on communications; adoption of resolutions,

247 Rules of Procedure of the African Commission, (n 104), Rule 118(4).

248 African Commission on Human and Peoples' Rights (Benghazi) $v$ Libya, Application 4/2011, Order for Provisional Measures (25 March 2011).

249 Ibid.

250 See e.g. Endorois, (n 99), paras 159-162, 164-165, 188-190, which relied on the following: Human Rights Committee, General Comment 22: Article 18 (Freedom of Thought, Conscience or Religion), UN Doc. CCPR/C/21/Rev.1/Add.4, (30 July 1993); Case of the Saramaka People v Suriname (IACtHR, Judgment of November 28, 2007); The Mayagna (Sumo) Awas Tingni Community v Nicaragua, (IACtHR, Judgment of August 31, 2001), (Ser. C) No. 79 (2001); and Dogan and others v Turkey, Applications 8803/02-8811/02, 8813/02 and 8815/o2-8819/o2 (ECtHR, 29 June 2004). 
principles/guidelines, general comments, model laws and advisory opinions; special rapporteurs and working groups to deal with thematic human rights issues; conducting on-site visits; consideration of State reports and adoption of concluding observations; as well as the referral of communications to the African Court.

Nevertheless, compliance with the Commission's 'requests' for provisional measures/letters of urgent appeals, decisions and recommendations of the Commission, as set out in the Communications and concluding observations on State reports, has been low. The insufficient funding of the Commission from the member States budget and human crisis at the Commission's Secretariat, impedes the Commission's capacity to follow-up on implementation as it prevents the Commission from developing effective follow up of its findings during country visits, and recommendations arising from its findings, resulting in the overall weakening of the effectiveness of the Commission. ${ }^{251}$

Although the contribution of the African Court is still modest, it is noteworthy that between 2006-March 2018 it has handed down judgments in 11 contentious cases (excluding admissibility decisions), finding violations in all of them. It also adopted one advisory opinion during the same period. Three main challenges to the Court limit its effectiveness.

First, the limited direct access by individuals and NGOs to the Court due to a limited number of States that have accepted the Court's jurisdiction and allowed individuals and NGOs direct access to the Court. ${ }^{252}$ Thus, there is a need for more States to ratify the Court's Protocol and to allow individuals and NG OS direct access to the Court. This will help to consolidate a pan-African judicial system for the protection of human rights which applies to over 1.2 billion people in Africa. In addition, an amendment of Article 34(6) the African Court Protocol by a decision of the AU Assembly of Heads of State and Government to allow individuals and NG Os direct access to the Court would make the Court more accessible to victims of human rights violations in Africa. Until this is achieved, the African Commission should submit more cases to the Court in accordance with Rule 118 discussed above, particularly those cases in which States have failed to implement the Commission's decisions.

251 See $4^{\text {nd }}$ Activity Report of the African Commission on Human and Peoples' Rights, <http://www.achpr.org/files/activity-reports/42/42nd_activity_report_eng.pdf>, February 2017 - May 2017, paras 45 and 52.

252 By March 2018, only eight out of 30 State parties to the African Court Protocol had accepted direct access to the Court by individuals and NGO . 
Second, the non-implementation of the Court's decisions, including refusals to implement, failure to inform the Court of what measures have been taken, and the slow pace or 'reluctance' to comply limits the Court's effectiveness. ${ }^{253}$ In 2013, for example, the Court adopted an Interim Report noting that 'Libya has failed to comply with a judgment of the Court'.254 It called on the AU Assembly of Heads of State to take such other measures as it deems appropriate to ensure that Libya fully complies with the Court Order. ${ }^{255}$ However, the Assembly did not take any action. This shows that non-compliance and non-enforcement applies to both the Commission's recommendations as well as the Court's orders. Thus the ability of the AU organs to impose sanctions consistently on non-complying States is necessary in order to strengthen the credibility of the African Court's orders and judgments.

Third, a lack of awareness about the African human rights system (AU human rights treaties and institutions including the African Commission and Court) by aggrieved individuals/groups and limited knowledge about the system by domestic lawyers limits potential applications to the Commission and the Court. Therefore, States and other actors including educational institutions should through human rights education raise awareness about the African Commission and Court among public and government officials and other actors including religious leaders, judges, lawyers, and law enforcement officials throughout Africa.

Finally, given the limited resources of the Commission and the Court, subsidiarity must be strengthened. ${ }^{256}$ Effective and accessible remedies before domestic and sub-regional courts will decrease the workload of the Commission and the Court. In the longer term, both the Commission and the Court must continue to examine ways to maintain their effectiveness and legitimacy in order to discharge their respective mandates.

253 See African Court, Mid-Term Activity Report, 1 January - 30 June 2017, paras 45-46; AU Executive Council, Report on the Activities of the African Court to the Executive Council, 22-27 January 2017 para 57 'While welcoming the efforts made by Burkina Faso and Tanzania to implement the Court's judgments, the Court notes that the two countries are yet to fully comply with the orders of the Court in those judgments, and further notes Tanzania's unwillingness to comply with the Court's Orders for Provisional Measures'.

254 African Court, Interim Report of the African Court notifying the Executive Council of non-compliance by a State (Interim Report on Libya), 17 May 2013 para 8.

255 Ibid, 9-10.

256 See Garreth Anver Prince v South Africa, Communication 255/02; (2004) AHRLR 105, paras $50-53$. 